Prepared in cooperation with Department of the Navy

Engineering Field Activity, Northwest

Naval Facilities Engineering Command

\title{
Selected Natural Attenuation Monitoring Data, Operable Unit 1, Naval Undersea Warfare Center, Division Keyport, Washington, June 2003
}

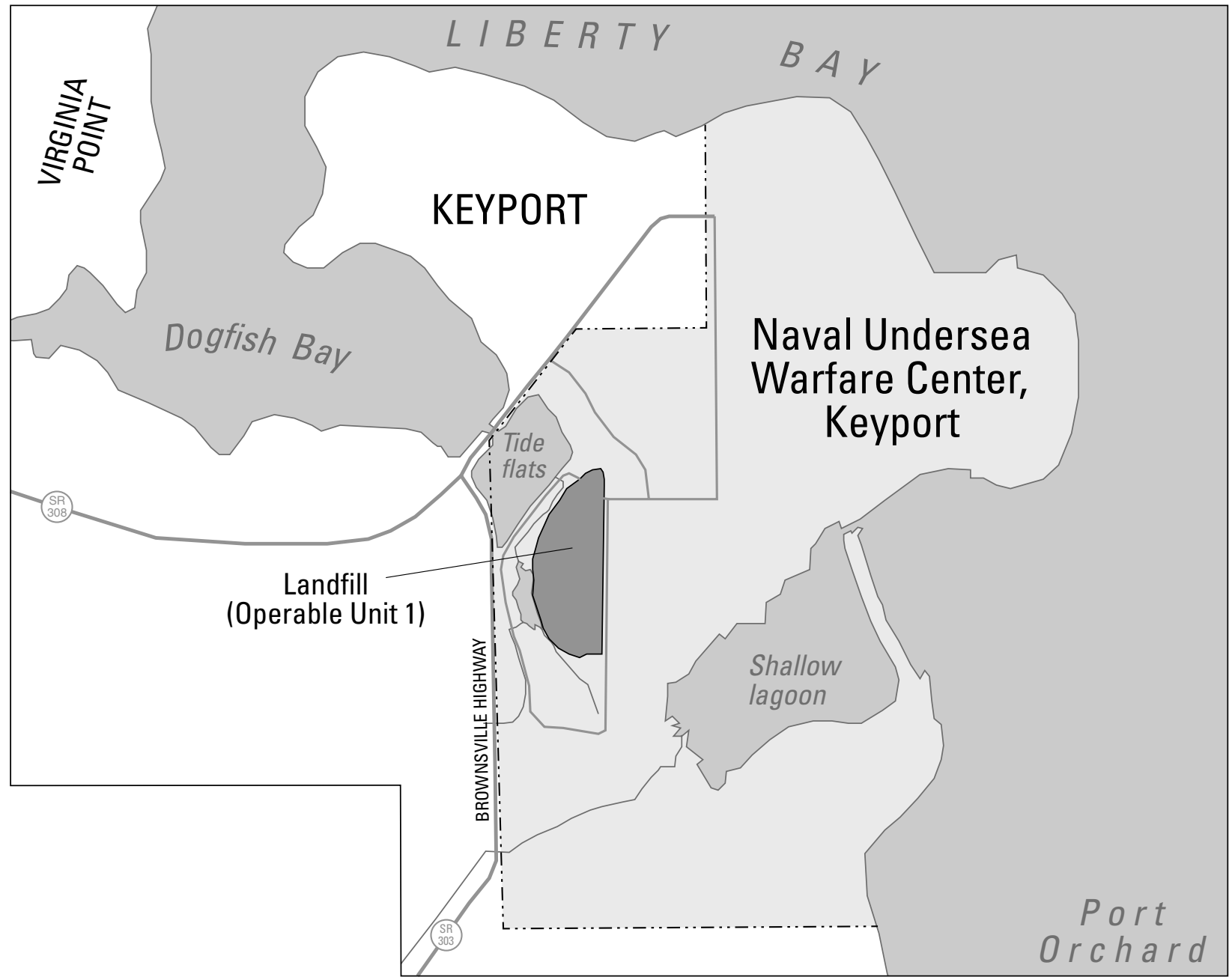

Open File Report 2004-1330

U.S. Department of the Interior

U.S. Geological Survey 


\section{Selected Natural Attenuation Monitoring Data, Operable Unit 1, Naval Undersea Warfare Center, Division Keyport, Washington, June 2003}

By R.S. Dinicola and R.L. Huffman

Prepared in cooperation with the Department of the Navy

Engineering Field Activity, Northwest

Naval Facilities Engineering Command

Open-File Report 2004-1330 


\title{
U.S. Department of the Interior \\ Gale A. Norton, Secretary \\ U.S. Geological Survey \\ Charles G. Groat, Director
}

\section{U.S. Geological Survey, Reston, Virginia: 2004}

\author{
For sale by U.S. Geological Survey, Information Services \\ Box 25286, Denver Federal Center \\ Denver, CO 80225 \\ For more information about the USGS and its products: \\ Telephone: 1-888-ASK-USGS \\ World Wide Web: http://www.usgs.gov/
}

\footnotetext{
Any use of trade, product, or firm names in this publication is for descriptive purposes only and does not imply endorsement by the U.S. Government.

Although this report is in the public domain, permission must be secured from the individual copyright owners to reproduce any copyrighted materials contained within this report.

Suggested citation:

Dinicola, R.S., and Huffman, R.L., 2004, Selected natural attenuation monitoring data, Operable Unit 1, Naval Undersea Warfare Center, Division Keyport, Washington, June 2003: U.S. Geological Survey Open-File Report 2004-1330, $19 \mathrm{p}$.
} 


\section{Contents}

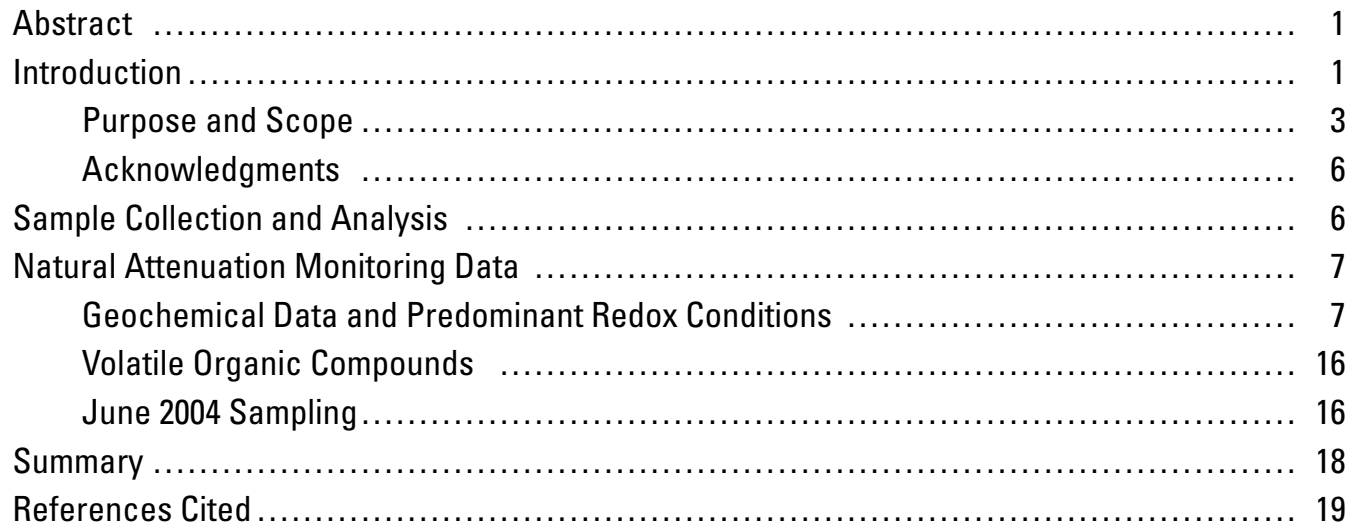

\section{Figures}

1. Map showing location of Operable Unit 1 study area, Naval Undersea Warfare Center, Division Keyport, Washington.

2. Map showing location of data-collection sites and other features at Operable Unit 1, Naval Undersea Warfare Center, Division Keyport, Washington, June 2003.

\section{Tables}

1. Construction data and water-level measurements for monitoring wells and piezometers sampled at Operable Unit 1, Naval Undersea Warfare Center, Division Keyport, Washington, June 2003

2. Predominant redox conditions and ground-water geochemical data collected at Operable Unit 1, Naval Undersea Warfare Center, Division Keyport, Washington, 1996 to 2003

3. Concentrations of selected chlorinated volatile organic compounds in ground water from piezometers and monitoring wells sampled by the U.S. Geological Survey at Operable Unit 1, Naval Undersea Warfare Center, Division Keyport, Washington, 1999 to 2003 


\section{Conversion Factors, Datums, and Abbreviations}

CONVERSION FACTORS

\begin{tabular}{lcl}
\hline Multiply & By & To obtain \\
acre & 4047 & square meter \\
acre & 0.4047 & hectare \\
feet (ft) & 0.3048 & meter \\
\hline
\end{tabular}

Temperature in degrees Celsius $\left({ }^{\circ} \mathrm{C}\right)$ may be converted to degrees Fahrenheit $\left({ }^{\circ} \mathrm{F}\right)$ as follows:

$$
{ }^{\circ} \mathrm{F}=1.8^{\circ} \mathrm{C}+32 \text {. }
$$

Temperature in degrees Fahrenheit $\left({ }^{\circ} \mathrm{F}\right)$ may be converted to degrees Celsius $\left({ }^{\circ} \mathrm{C}\right)$ as follows:

$$
{ }^{\circ} \mathrm{C}=\left({ }^{\circ} \mathrm{F}-32\right) / 1.8 \text {. }
$$

Concentrations of chemical constituents in water are given in milligrams per liter, micrograms per liter, or nanomoles per liter (nanomolar). One milligram per liter is equivalent to one thousand micrograms per liter. One microgram per liter is equivalent to "parts per billion."

DATUMS

Vertical coordinate information is referenced to the North American Vertical Datum of 1988 (NAVD of 1988). Horizontal coordinate information is referenced to the NAD27.

ABBREVIATIONS

Organizations

USGS U.S. Geological Survey

EFANW Naval Facilities Engineering Command, Engineering Field Activity, Northwest

NUWC Naval Undersea Warfare Center

NWIS National Water Information System

NWQL National Water Quality Laboratory

\section{Other}

CA chloroethane

cis-DCE cis-1,2-dichloroethene

CVOCs chlorinated volatile organic compounds

DO dissolved oxygen

$\mathrm{H}_{2} \quad$ dissolved hydrogen

$\mathrm{nM}$ nanomolar

$\mathrm{mg} / \mathrm{L} \quad$ milligram per liter

ORP oxidation-reduction potential

OU 1 operable Unit 1

TCA 1,1,1-trichloroethane

TCE trichloroethene

VC vinyl chloride

VOC volatile organic compound

$\mu \mathrm{m} \quad$ micrometer

1,1-DCA 1,1-dichloroethane

1,1-DCE 1,1-dichloroethene 


\title{
Selected Natural Attenuation Monitoring Data, Operable Unit 1, Naval Undersea Warfare Center, Division Keyport, Washington, June 2003
}

\author{
By R.S. Dinicola and R.L. Huffman
}

\author{
Abstract \\ Previous investigations have shown that natural \\ attenuation and biodegradation of chlorinated volatile organic \\ compounds (CVOCs) are substantial in shallow ground \\ water beneath the 9-acre former landfill at Operable Unit 1 \\ (OU 1), Naval Undersea Warfare Center (NUWC), Division \\ Keyport, Washington. This report presents the ground-water \\ geochemical and selected CVOC data collected at OU 1 by the \\ U.S. Geological Survey (USGS) during June 17-20, 2003 in \\ support of long-term monitoring for natural attenuation. \\ Strongly reducing conditions favorable for reductive \\ dechlorination of CVOCs were found in fewer upper-aquifer \\ wells during June 2003 than were found during sampling \\ periods in 2001 and 2002. Redox conditions in water from \\ the intermediate aquifer just downgradient from the landfill \\ remained somewhat favorable for reductive dechlorination. \\ As was noted in previous monitoring reports, the changes in \\ redox conditions observed at individual wells have not been \\ consistent or substantial throughout either the upper or the \\ intermediate aquifers. \\ Compared to 2002 data, total CVOC concentrations \\ in June 2003 were nearly unchanged in all northern \\ plantation piezometers sampled, although the concentrations \\ were historically low at two of those sites. Total CVOC \\ concentrations decreased consistently in the southern \\ plantation samples. Historically low total CVOC \\ concentrations were observed in three of the piezometers \\ sampled, and a two order-of-magnitude decrease in total
}

CVOCs was observed at one of those sites. The observed decreases in CVOC concentrations appear to be in contrast with the 2003 redox data that suggested less favorable conditions for reductive dechlorination. The Navy and USGS plan to do more extensive data-collection and interpretation during 2004 to better understand and document possible changes in redox conditions and contaminant biodegradation.

\section{Introduction}

Chlorinated volatile organic compounds (CVOCs) have migrated to ground water beneath a 9-acre former landfill at Operable Unit 1 (OU 1) of the Naval Undersea Warfare Center (NUWC), Division Keyport. The NUWC is a small peninsula in Kitsap County, Washington, in an extension of Puget Sound called Liberty Bay (fig. 1). The former landfill at OU 1 is on the narrow strip of land connecting the peninsula to the mainland and is adjacent to tidal flats that are an extension of Dogfish and Liberty Bays. The OU 1 landfill is unlined at the bottom and was constructed in a former marshland. The landfill was the primary disposal area for domestic and industrial wastes generated by NUWC Keyport from the 1930s through 1973. Paints, thinners, solvents, acids, dried sludge from a wastewater-treatment plant, and other industrial wastes were disposed in the landfill. The most concentrated disposal area for waste paints and solvents was at the southern end of the landfill. 


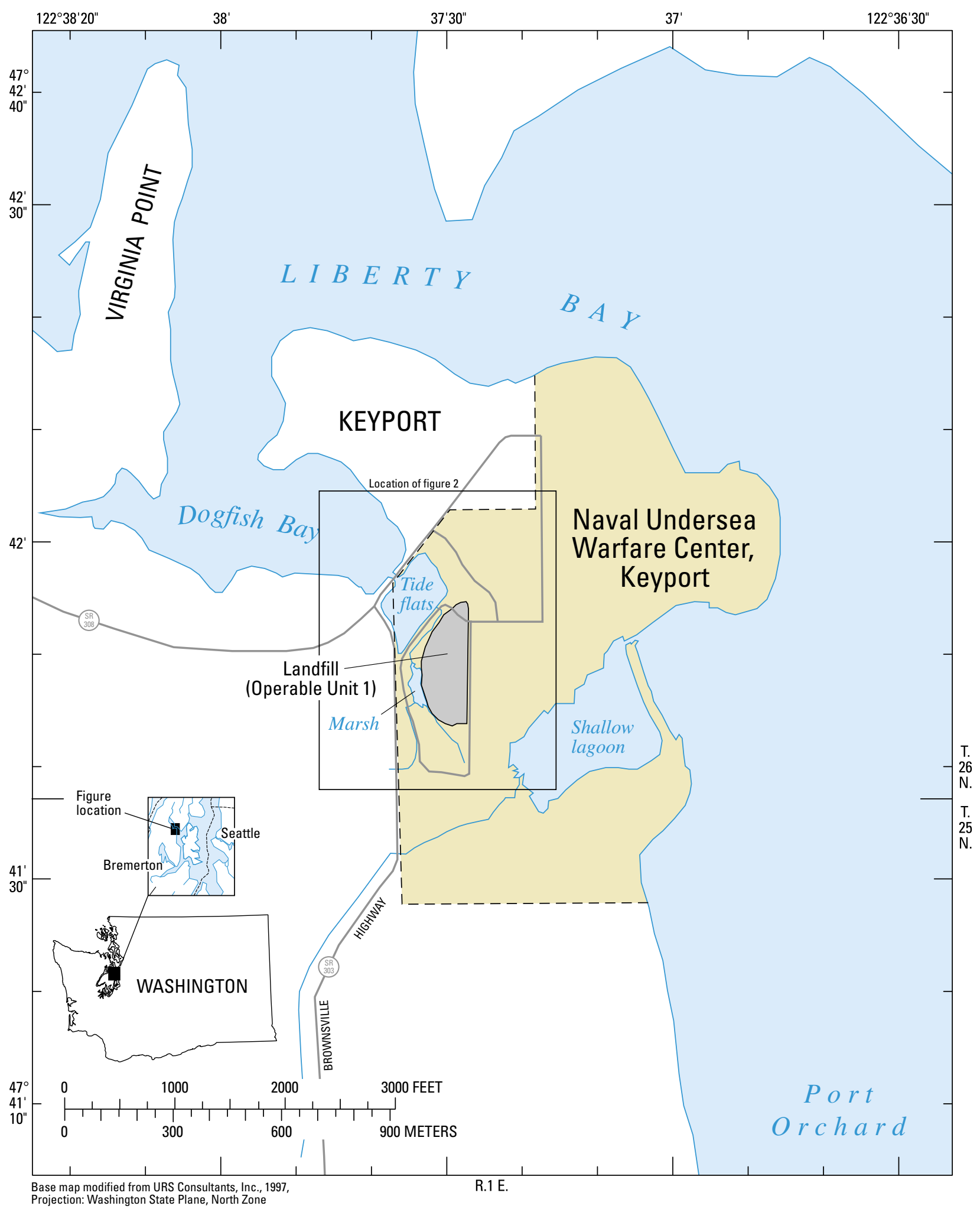

Figure 1. Location of Operable Unit 1 study area, Naval Undersea Warfare Center, Division Keyport, Washington. 
CVOCs are present in the upper and intermediate aquifers and in surface water at OU 1. Ground water beneath OU 1 occurs within a series of aquifers that are composed of permeable sand, gravel, or fill materials separated by finegrained silt or clay layers. Contamination at OU 1 is known to occur only in about the top 60 feet of the unconsolidated deposits in the hydrogeologic units referred to as the unsaturated zone, the upper aquifer, the middle aquitard, and the intermediate aquifer. Water in the unconfined upper aquifer generally flows from east to west toward Dogfish Bay. Water in the predominately confined intermediate aquifer flows from the south and west toward the landfill, and then northwest from the landfill toward Dogfish bay (Dinicola and others, 2002). Two perennial freshwater creeks drain the marsh adjacent to the landfill and discharge into the tideflats of Dogfish Bay.

The predominant contaminants in ground water beneath OU1 are trichloroethene (TCE) and its degradation byproducts cis-1,2-dichloroethene (cis-DCE) and vinyl chloride (VC). The compound 1,1,1-trichloroethane (TCA) and its degradation byproducts 1,1-dichloroethane (1,1-DCA), 1,1-dichloroethene (1,1-DCE), and chloroethane (CA) have been detected at concentrations of concern at a few locations at OU 1. A need for remedial action was identified because those compounds present a potential health risk to humans (URS Consultants, Inc., 1998). Phytoremediation combined with on-going natural attenuation processes was chosen by the Navy as the preferred remedy for reducing or eliminating that risk (URS Consultants, Inc., 1998). The Navy planted two hybrid poplar plantations on the landfill (ig. 2) in spring of 1999 to remove and control the migration of CVOCs in shallow ground water (URS Greiner, Inc., 1999). The landfill between the plantations is covered with pavement, but the area north of the northern plantation is permeable.

\section{Purpose and Scope}

The Navy began a cooperative effort with the USGS in 1995 to investigate various natural attenuation mechanisms at OU 1. Field and laboratory studies conducted from 1996 through 2000 have shown that natural attenuation and biodegradation of CVOCs in shallow ground water at OU 1 is substantial (URS Consultants, Inc., 1997; Bradley and others, 1998; Dinicola and others, 2002). The USGS has continued to monitor the geochemistry of ground water to assure that conditions remain favorable for contaminant biodegradation.

This report presents ground-water chemical and selected CVOC data collected by the USGS at OU 1 during June 1720, 2003 in support of the long-term monitoring for natural attenuation. USGS data collected from 1996 through 2002 were presented in Dinicola and others (2002), Dinicola (2003), and Dinicola (2004). In June 2003, the USGS collected water samples from 12 wells and 9 piezometers (table 1 and fig. 2); data collection focused on constituents that could be used to evaluate ground-water redox conditions. Concentrations of various chemical constituents were determined in all samples; however, concentrations of CVOCs were determined by the USGS in samples from all 9 piezometers but in samples from only 3 of the 12 monitoring wells. The Navy collected samples from other OU 1 monitoring wells during April 2003 to determine concentrations of CVOCs; those data are presented in a different report (The TEC LTM Team, 2004) The June 2003 data were not interpreted in detail for this report because natural attenuation at $\mathrm{OU} 1$ will again be thoroughly evaluated in support of the 5-year review scheduled for 2005. 


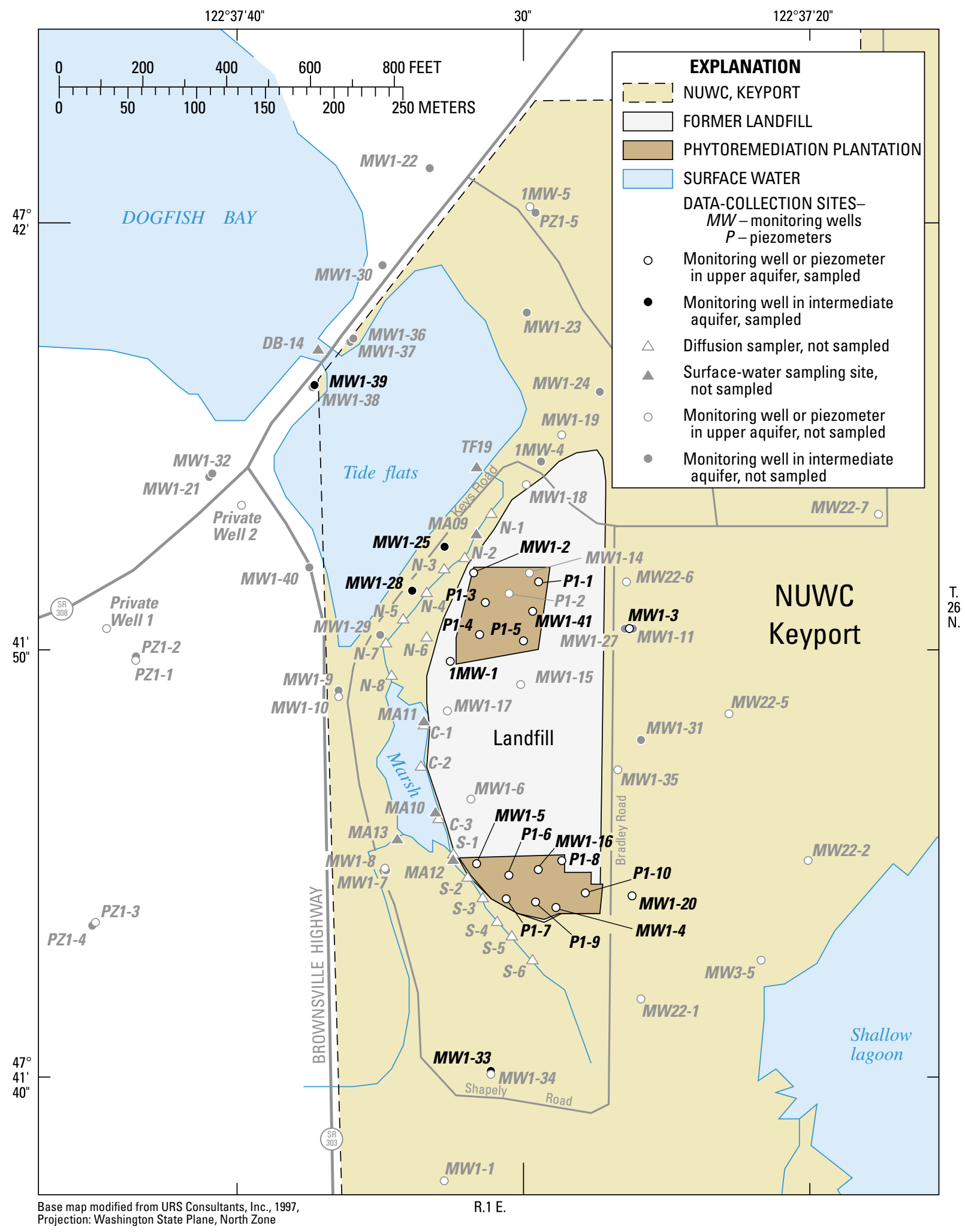

Figure 2. Location of data-collection sites and other features at Operable Unit 1, Naval Undersea Warfare Center, Division Keyport, Washington, June 2003. 
Table 1. Construction data and water-level measurements for monitoring wells and piezometers sampled at Operable Unit 1, Naval Undersea Warfare Center, Division Keyport, Washington, June 2003

[Well No.: MW, monitoring well; P, piezometer. USGS site No.: Unique number for each site based on latitude and longitude of the site. First six digits are latitude, next seven digits are longitude, and final two digits are a sequence number to uniquely identify each site. Altitudes of water levels and measuring points are given in feet above or below (-) NAVD88. Water level is in feet below measuring point (bmp). Depth of well and screened interval are in feet below land surface. Measuring point: Water levels in wells are usually reported as depths below land surface, although the measuring point can be any convenient fixed place near the top of the well. For these wells and piezometers, the measuring points are marked points on the tops of well casings-they vary from being near the land surface to a few feet above land surface. The altitude of the measuring point is commonly recorded so that static water levels also can be reported as altitudes. Abbreviations: ft, foot; in, inch; USGS, U.S. Geological Survey; ROD, Record of Decision; dup, field duplicate sample; VOCs, volatile organic compounds]

\begin{tabular}{|c|c|c|c|c|c|c|c|c|c|c|c|c|}
\hline Well No. & USGS site No. & Date & $\begin{array}{c}\text { Time } \\
\text { sampled }\end{array}$ & $\begin{array}{l}\text { Water- } \\
\text { level } \\
\text { altitude } \\
\text { (ft) }\end{array}$ & $\begin{array}{c}\text { Water- } \\
\text { level } \\
\text { (ft bmp) }\end{array}$ & $\begin{array}{c}\text { Altitude } \\
\text { of mea- } \\
\text { suring } \\
\text { point }(\mathrm{ft})\end{array}$ & $\begin{array}{c}\text { Depth of } \\
\text { well } \\
\text { (ft) }\end{array}$ & $\begin{array}{l}\text { Casing } \\
\text { diameter } \\
\text { (in.) }\end{array}$ & $\begin{array}{c}\text { Screened } \\
\text { interval } \\
\text { (ft) }\end{array}$ & VOCs sa & pled by & $\begin{array}{l}\text { Geochem- } \\
\text { ical } \\
\text { sampling } \\
\text { specified in } \\
\text { ROD }\end{array}$ \\
\hline 1MW-1 & 474151122373201 & $06-17-03$ & $16: 00$ & 3.06 & 7.00 & 10.06 & 16.5 & 2 & $5.5-15.5$ & & $\mathrm{X}$ & $\mathrm{X}$ \\
\hline MW1-2 & 474153122373101 & $06-18-03$ & $10: 25$ & 1.84 & 10.05 & 11.89 & 18.5 & 4 & $12.5-17.5$ & & $\mathrm{X}$ & $\mathrm{X}$ \\
\hline MW1-3 & 474152122372501 & $06-17-03$ & $13: 00$ & 9.34 & 4.21 & 13.55 & 11.5 & 4 & $5.5-10.5$ & & $\mathrm{X}$ & \\
\hline MW1-5 & 474146122373201 & $06-20-03$ & $13: 20$ & 4.33 & 8.75 & 13.08 & 12.0 & 4 & $6-11$ & & $X$ & $X$ \\
\hline MW1-16 & 474146122372801 & $06-20-03$ & $15: 15$ & 5.53 & 7.30 & 12.83 & 12.0 & 2 & $6-11$ & & $\mathrm{X}$ & $X$ \\
\hline MW1-20 & 474145122372501 & $06-17-03$ & $15: 05$ & 6.68 & 3.76 & 10.44 & 16.0 & 2 & $10-15$ & & $\mathrm{X}$ & \\
\hline MW1-25 & 474154122373201 & $06-19-03$ & $12: 10$ & 2.29 & 9.62 & 11.91 & 49.0 & 2 & $38-48$ & $\mathrm{X}$ & & $\mathrm{X}$ \\
\hline MW1-28 & 474153122373301 & 06-19-03 & 11:00 & -.75 & 10.98 & 10.23 & 45.0 & 2 & $39-44$ & $\mathrm{X}$ & & $\mathrm{X}$ \\
\hline MW1-33 & 474140122373201 & $06-17-03$ & $12: 00$ & 11.12 & .38 & 11.50 & 41.0 & 2 & $30-40$ & & & \\
\hline P1-3 & 474153122373101 & 06-18-03 & $11: 30$ & 3.21 & 9.58 & 12.79 & 15.0 & 1 & $10-15$ & $\mathrm{X}$ & & \\
\hline P1-4 & 474152122373101 & $06-18-03$ & $12: 30$ & 4.74 & 7.81 & 12.55 & 15.0 & 1 & $10-15$ & $\mathrm{X}$ & & \\
\hline $\begin{array}{l}\text { P1-5 } \\
\text { (dup) }\end{array}$ & 474152122372801 & 06-18-03 & $\begin{array}{l}15: 45 \\
15: 46\end{array}$ & 5.89 & 9.17 & 15.06 & 15.0 & 1 & $10-15$ & $\mathrm{X}$ & & \\
\hline P1-6 & 474146122373001 & $06-20-03$ & $14: 00$ & 5.39 & 7.37 & 12.76 & 15.0 & 1 & $10-15$ & $\mathrm{X}$ & & \\
\hline P1-7 & 474145122373101 & $06-20-03$ & $11: 55$ & 5.23 & 6.89 & 12.12 & 15.0 & 1 & $10-15$ & $\mathrm{X}$ & & \\
\hline P1-8 & 474147122372801 & $06-20-03$ & $16: 00$ & 6.19 & 5.87 & 12.06 & 15.0 & 1 & $10-15$ & $\mathrm{X}$ & & \\
\hline P1-9 & 474145122372901 & $06-20-03$ & 10:00 & 5.48 & 6.43 & 11.91 & 15.0 & 1 & $10-15$ & $\mathrm{X}$ & & \\
\hline P1-10 & 474145122372601 & 06-19-03 & $14: 00$ & 6.59 & 5.27 & 11.86 & 15.0 & 1 & $10-15$ & $\mathrm{X}$ & & \\
\hline
\end{tabular}




\section{Acknowledgments}

The author thanks Douglas Thelin of the Naval Facilities Engineering Command, Engineering Field Activity, Northwest (EFANW) for his guidance and for securing funding for the continued monitoring. Mick Butterfield of EFANW and Gene Ellis of NUWC Keyport provided logistic support for field activities. Stephen Cox, Raegan Huffman, C.G. Laird, Anthony Paulson, and Bill Simonds of U.S. Geological Survey, Tacoma, Washington, assisted with data collection and analysis.

\section{Sample Collection and Analysis}

Sample collection, processing, and field analyses were in accordance with applicable USGS procedures (U.S. Geological Survey, 1997 to 2002). The analytical methods used for the June 2003 data-collection activities were generally consistent with previous USGS data-collection activities at $\mathrm{OU} 1$.

The geochemical measurements and concentrations determined for samples from all wells and piezometers included dissolved hydrogen $\left(\mathrm{H}_{2}\right)$, dissolved oxygen (DO), filtered organic carbon, filtered nitrate plus nitrite, filtered manganese, filtered iron (II), filtered sulfate, unfiltered sulfide, dissolved methane, dissolved carbon dioxide, $\mathrm{pH}$, specific conductance, oxidation-reduction potential (ORP), and filtered chloride. The concentrations of 64 VOCs, including all CVOCs of interest at OU 1, also were determined for samples from the piezometers and from selected monitoring wells. Monitoring wells and piezometers sampled at OU 1 are of different depths and diameters (table 1), but all were constructed with PVC casings and screens with sand filter packs.

All samples were collected with a peristaltic pump and single-use polyurethane tubing. A stainless-steel weight was attached to the bottom of the pre-measured length of tubing to accurately collect the sample from the mid-screen elevation in each well or piezometer. Samples were collected after approximately three casing-volumes of water were purged from the wells or piezometers and after allowing $\mathrm{pH}$, specific conductance, and DO to stabilize within 0.1 units, 5 percent, and $0.3 \mathrm{mg} / \mathrm{L}$, respectively. Those three analytes, as well as oxidation-reduction potential, were measured in a flowthrough chamber using temperature compensated probes from a YSI ${ }^{\mathrm{TM}}$ data sonde. The specific conductance probe was checked daily with standard reference solutions; the $\mathrm{pH}$ probe was calibrated daily with two $\mathrm{pH}$ standards; and the dissolved oxygen probe was calibrated daily with water-saturated air and occasionally verified with zero dissolved-oxygen solution.
Dissolved-oxygen analyses were confirmed for most samples using 0 to 1 milligram per liter $(\mathrm{mg} / \mathrm{L})$ CHEMets Rhodazine$\mathrm{D}^{\mathrm{TM}}$ colorimetric ampoules (manufactured by CHEMetrics, Inc., Calverton, Virginia.). The ampoules were filled directly from the sampling tube after well purging was complete.

Concentrations of iron (II) were measured in the field in a sample filtered through a $0.45-\mu \mathrm{m}$ membrane filter using a colorimetric 1,10 phenanthroline indicator method and a Hach Model 2010 spectrophotometer according to Hach analytical method number 255 (Hach Company, 1998). Concentrations of sulfide were measured in the field using a colorimetric methylene-blue indicator method immediately using the same spectrophotometer according to analytical method number 690 (Hach Company, 1998). Information about the methodologies used to determine iron and sulfide concentrations is described at http://www.hach.com. Concentrations of dissolved carbon dioxide $\left(\mathrm{CO}_{2}\right)$ were measured in the field using Titret ${ }^{\circledR}$

Sodium hydroxide tirtrant with a $\mathrm{pH}$ indicator (manufactured by CHEMetrics, Inc., Calverton, Virginia). In previous years, alkalinity titrations were performed on samples to determine bicarbonate concentrations as an analog measure of $\mathrm{CO}_{2}$ concentrations, but the recent availability of the field test kits makes direct measurement more desirable. $\mathrm{CO}_{2}$ concentrations were measured in a laboratory during 2002, and alkalinity was measured in the field.

Dissolved $\mathrm{H}_{2}$ in ground water was sampled using the bubble-strip method of Chapelle and others (1997) and concentrations were measured in the field using a gas chromatograph equipped with a reduction gas detector. Initial gas samples from each well or piezometer were collected and analyzed after at least 20 minutes of stripping; subsequent samples were collected and analyzed at about 5-minute intervals until consecutive $\mathrm{H}_{2}$ concentrations stabilized to within 10 percent, a process that often required an hour or more. If dissolved $\mathrm{H}_{2}$ did not stabilize and did not consistently increase or decrease after approximately one hour, the range over which the concentrations fluctuated was reported.

Samples for analysis of nitrate, manganese, sulfate, and chloride were filtered through a $0.45-\mu \mathrm{m}$ membrane filter into polyethylene bottles, chilled, and sent to the USGS National Water Quality Laboratory (NWQL) in Lakewood, Colorado. The manganese sample was acidified in the field with nitric acid to a pH of less than 2, and then analyzed at NWQL by inductively coupled plasma as described by Fishman (1993). Chloride and sulfate were analyzed using ion chromatography as described by Fishman and Friedman (1989). Nitrate plus nitrite (reported as nitrite plus nitrate as $\mathrm{N}$ ) were analyzed calorimetrically by cadmium reduction and diazotization as described by Fishman (1993). The results for the nitrate plus nitrite analyses are referred to simply as nitrate in this report because of the expected small contribution of nitrite to the total concentration determined. 
Samples for analysis of dissolved organic carbon were filtered through a $0.45-\mu \mathrm{m}$ filter, collected in amber glass bottles, acidified in the field with sulfuric acid to a $\mathrm{pH}$ of less than 2 , chilled to less than $4^{\circ} \mathrm{C}$, and shipped to the USGS laboratory in Ocala, Florida, for analysis. Organic carbon concentrations were determined using high temperature combustion according to Standard Method 5310B as described by Franson (1992).

Samples for analysis of dissolved methane were collected in 150-mL glass bottles, sealed with rubber stoppers, chilled to less than $4^{\circ} \mathrm{C}$, and analyzed at the U.S. Geological Survey Laboratory in Tacoma, Washington. Samples were analyzed using a gas chromatograph with a flame-ionization detector as described by Kambell and others (1989).

Samples for analysis of CVOCs were collected in preacidified 40-mL glass vials, placed on ice, and shipped to the Severn Trent Laboratories (STL) in Denver, Colorado, for analysis using purge and trap capillary-column gas chromatography/mass spectrometry (USEPA Method 8260B).

\section{Natural Attenuation Monitoring Data}

The data collected in support of long-term monitoring for natural attenuation included geochemical and selected CVOC data. The predominant redox conditions at each sample location were determined from the geochemical data.

\section{Geochemical Data and Predominant Redox Conditions}

The June 2003 data and the previous geochemical data collected by USGS at OU 1 (Dinicola and others, 2002; Dinicola, 2003; and Dinicola, 2004) are shown in table 2. A duplicate sample collected from well MW1-41 was analyzed for organic carbon, manganese, sulfate, and chloride. The duplicate results for those constituents agreed within 5 percent. As mentioned previously, OU 1 samples were not analyzed for $\mathrm{CO}_{2}$ prior to 2002 , but these analyses have been made since then because the analyte is of interest in the analysis of natural attenuation. The concentration of $\mathrm{CO}_{2}$ is a direct measure of the primary byproduct of microbial respiration, whereas bicarbonate concentration is only an indirect measure of the carbon dioxide concentration. Therefore samples collected during June 2003 were not analyzed for bicarbonate.

The predominant redox conditions for June 2003 samples were determined primarily on the basis of dissolved oxygen and dissolved $\mathrm{H}_{2}$ concentrations. The process and uncertainties in determining the predominant redox conditions from geochemical data are described in detail in Dinicola and others (2002). Generally, dissolved-oxygen concentrations greater than $1 \mathrm{mg} / \mathrm{L}$ indicate aerobic conditions, and concentrations less than $1 \mathrm{mg} / \mathrm{L}$ indicate anaerobic conditions.
More specific anaerobic conditions are indicated by dissolved $\mathrm{H}_{2}$ concentrations: $0.2-0.8$ nanomolar $(\mathrm{nM})$ indicate iron reduction, 1 to $5 \mathrm{nM}$ indicate sulfate reduction, and greater than $5 \mathrm{nM}$ indicate methanogenesis. Anaerobic ground water with a dissolved $\mathrm{H}_{2}$ concentration less than $1 \mathrm{nM}$ (manganese and iron reduction) is referred to as mildly reducing, and water with a dissolved $\mathrm{H}_{2}$ concentration greater than $1 \mathrm{nM}$ (sulfate reduction and methanogensis) is referred to as strongly reducing. These general terms for describing anaerobic redox conditions are useful because reductive dechlorination of CVOCs is more likely to occur under strongly reducing conditions (Gossett and Zinder, 1996; McCarty and Semprini, 1994).

In June 2003, the strongly reducing conditions most favorable for reductive dechlorination of CVOCs were identified in 4 of 15 samples from the upper aquifer beneath the landfill, whereas analyses of most other upper aquifer samples indicated mildly reducing conditions. In contrast, the majority of upper-aquifer samples from beneath the landfill indicated strongly reducing conditions during 2001 and 2002. It is not clear if these results indicate a long-term trend towards less reducing conditions in the upper aquifer or simply a significant interannual variability. The historical data on redox conditions have often varied significantly from year to year. For example, conditions in wells MW-2 and MW-20 have shifted from iron reducing to sulfide reducing to anaerobic and back to iron reducing from 2000 to 2003. Redox conditions in water from the intermediate aquifer just downgradient from the landfill (wells MW1-25 and MW1-28) also remained somewhat favorable for reductive dechlorination. As was noted in previous annual monitoring reports, the changes in redox conditions observed at individual wells have not been consistent or substantial throughout either the upper or the intermediate aquifers. At least an additional year of monitoring data and more thorough interpretation are needed to ascertain if phytoremediation activities are affecting redox condition and if conditions favorable for continued biodegradation are changing over time. In support of the 5year review data and conditions at OU 1 scheduled for 2005, the Navy and USGS plan to do more extensive data-collection and interpretation during 2004 in order to better understand and document possible changes in redox conditions.

The previous USGS monitoring report for OU 1 (Dinicola, 2004) hypothesized that the practice of deploying a data sonde downhole while purging a well created abnormally high and non-equilibrium concentrations of dissolved $\mathrm{H}_{2}$. The 2003 data support the hypothesis that the deployment of the sonde downhole during the purging of wells in 2002 did result in non-representative dissolved $\mathrm{H}_{2}$ concentrations. Thus the data sonde was not deployed while purging any wells during June 2003, and previously high (>20 nM) concentration of $\mathrm{H}_{2}$ in wells all decreased back to concentrations similar to pre2002 historical data. 
Table 2. Predominant redox conditions and ground-water geochemical data collected at Operable Unit 1, Naval Undersea Warfare Center, Division Keyport, Washington, 1996 to 2003

[All data except those shaded were published previously in Dinicola and others (2002), Dinicola (2003 and 2004). 2002 dissolved methane and carbon dioxide concentrations were collected and analyzed in duplicate. Predominant redox conditions: A, aerobic; Fe, iron reducing; M, methanogenic; Mn, manganese reducing; S, sulfate reducing. Abbreviations: $\mathrm{nM}$, nanomolar; $\mathrm{mg} / \mathrm{L}$, milligram per liter; $\mu \mathrm{S} / \mathrm{cm}$, microsiemen per centimeter at $25^{\circ} \mathrm{Celsius;} \mathrm{mV}$, millivolt; ORP, oxygen reduction potential. Symbols: <, actual value is less than value shown; >, actual value is greater than value shown; -, not analyzed]

\begin{tabular}{|c|c|c|c|c|c|c|c|c|c|}
\hline $\begin{array}{c}\text { Piezometer } \\
\text { or } \\
\text { Well No. }\end{array}$ & $\begin{array}{c}\text { Date } \\
\text { sampled }\end{array}$ & $\begin{array}{c}\text { Predominant } \\
\text { redox } \\
\text { condition }\end{array}$ & $\begin{array}{c}\text { Dissolved } \\
\text { hydrogen } \\
\text { (nM) }\end{array}$ & $\begin{array}{c}\text { Dissolved } \\
\text { oxygen } \\
\text { (mg/L) }\end{array}$ & $\begin{array}{c}\text { Unfiltered } \\
\text { (total) organic } \\
\text { carbon (mg/L) }\end{array}$ & $\begin{array}{c}\text { Filtered } \\
\text { (dissolved) } \\
\text { organic } \\
\text { carbon (mg/L) }\end{array}$ & $\begin{array}{c}\text { Filtered } \\
\text { nitrate } \\
\text { +nitrite } \\
\text { (mg/L as } \mathrm{N} \text { ) }\end{array}$ & $\begin{array}{c}\text { Filtered } \\
\text { manganese } \\
(\mathbf{m g} / \mathrm{L})\end{array}$ & $\begin{array}{c}\text { Filtered } \\
\text { iron (II) } \\
(\mathrm{mg} / \mathrm{L})\end{array}$ \\
\hline \multirow[t]{8}{*}{$1 \mathrm{MW}-1$} & $09-17-96$ & $\mathrm{Fe}$ & 0.4 & 2.8 & 7.0 & - & $<0.02$ & 0.18 & 0.24 \\
\hline & $04-16-97$ & $\mathrm{Fe}$ & .8 & .4 & - & - & .11 & - & 8.0 \\
\hline & $03-05-98$ & $\mathrm{Fe} / \mathrm{S}$ & .2 & .1 & 8.3 & - & - & .39 & 12 \\
\hline & $10-09-98$ & $\mathrm{Fe}$ & .2 & .5 & - & - & - & .08 & .39 \\
\hline & $06-21-00$ & $\mathrm{Mn} / \mathrm{Fe}$ & .1 & .5 & 12 & - & $<.05$ & .96 & 13 \\
\hline & 06-11-01 & $\mathrm{Fe}$ & .6 & .7 & 13 & 12 & $<.05$ & .24 & 2.9 \\
\hline & 06-10-02 & $\mathrm{Fe}$ & .4 & .2 & 14 & - & $<.05$ & .37 & 7.3 \\
\hline & $06-17-03$ & $\mathrm{Fe}$ & .1 & .1 & - & 10 & $<.06$ & .17 & 1.2 \\
\hline \multirow[t]{2}{*}{$1 \mathrm{MW}-4$} & 09-17-96 & $\mathrm{Fe}$ & .6 & 1.6 & 23 & - & $<.02$ & .77 & 1.5 \\
\hline & 04-16-97 & $\mathrm{S}$ & 1.8 & .0 & - & - & .03 & - & 1.7 \\
\hline \multirow[t]{9}{*}{ MW1-2 } & $09-17-96$ & A & .5 & 2.4 & 6.0 & - & $<.02$ & .05 & .23 \\
\hline & 04-16-97 & $\mathrm{Fe}$ & .7 & .2 & - & - & $<.02$ & - & .13 \\
\hline & $03-02-98$ & $\mathrm{Fe}$ & .3 & - & - & - & - & - & .16 \\
\hline & $10-07-98$ & $\mathrm{Fe}$ & .1 & .1 & - & - & - & .05 & .14 \\
\hline & 06-09-99 & $\mathrm{Fe}$ & .9 & .2 & - & - & - & .08 & .09 \\
\hline & $06-21-00$ & $\mathrm{Fe}$ & .3 & .1 & 6.0 & - & $<.05$ & .06 & .10 \\
\hline & $06-12-01$ & $S$ & 3.5 & .3 & 5.3 & 5.0 & $<.05$ & .08 & .29 \\
\hline & $06-11-02$ & An & $>20$ & .1 & 45 & - & $<.05$ & .09 & .27 \\
\hline & 06-18-03 & $\mathrm{Fe}$ & .2 & .1 & - & 6 & $<.06$ & .10 & .29 \\
\hline \multirow[t]{5}{*}{ MW1-3 } & 06-09-99 & $\mathrm{Fe}$ & .8 & .4 & - & - & - & .07 & $<.01$ \\
\hline & $06-20-00$ & $\mathrm{Fe}$ & .2 & .3 & 2.0 & - & .99 & .08 & $<.01$ \\
\hline & $06-12-01$ & A & - & 4.0 & 2.3 & 1.1 & 1.1 & .04 & .02 \\
\hline & 06-10-02 & $S$ & 2.7 & .4 & 1.4 & - & 1.6 & .10 & .01 \\
\hline & $06-17-03$ & A & - & 4.3 & - & 1.7 & 1.8 & .09 & .05 \\
\hline \multirow[t]{9}{*}{ MW1-4 } & 09-17-96 & $\mathrm{Fe}$ & .5 & 2.8 & 2.0 & - & $<.02$ & .28 & 1.8 \\
\hline & $04-16-97$ & $\mathrm{Fe}$ & .6 & .4 & - & - & .24 & - & $<.01$ \\
\hline & 03-03-98 & $S$ & 1.7 & .2 & 4.0 & - & - & .10 & .01 \\
\hline & $10-08-98$ & $\mathrm{Fe}$ & .2 & .5 & - & - & - & - & .28 \\
\hline & 06-07-99 & $\mathrm{Fe}$ & .9 & .1 & - & - & - & .20 & 1.2 \\
\hline & $06-22-00$ & $\mathrm{Fe}$ & .2 & .1 & 8.6 & - & - & .70 & - \\
\hline & 06-14-01 & $\mathrm{S}$ & $.9-3.2$ & .5 & 2.9 & 2.5 & .08 & .54 & 1.6 \\
\hline & $06-13-02$ & $\mathrm{~S}$ & 2.4 & .1 & 3.8 & - & .08 & .47 & 1.2 \\
\hline & $06-20-03$ & $\mathrm{Fe}$ & .8 & .1 & - & 2.5 & $<.06$ & .53 & .22 \\
\hline \multirow[t]{9}{*}{ MW1-5 } & 09-17-96 & $\mathrm{S}$ & 1.2 & .0 & 15 & - & $<.02$ & 1.6 & 19 \\
\hline & $04-16-97$ & $\mathrm{Fe}$ & .5 & .0 & - & - & .08 & - & 3.1 \\
\hline & 03-04-98 & $\mathrm{Fe}$ & .7 & .0 & 12 & - & - & 1.3 & 4.5 \\
\hline & $10-08-98$ & $S$ & 2.4 & .0 & - & - & - & 1.5 & 11 \\
\hline & 06-08-99 & $\mathrm{Fe}$ & .6 & .3 & - & - & - & 1.2 & 31 \\
\hline & $06-22-00$ & $\mathrm{Fe}$ & - & .0 & 17 & - & - & 1.5 & 39 \\
\hline & 06-13-01 & $\mathrm{Fe}$ & .8 & .3 & 10 & 9.6 & .12 & 1.5 & 25 \\
\hline & $06-13-02$ & $\mathrm{~S}$ & 3.4 & .5 & 11 & - & .14 & 1.5 & 20 \\
\hline & $06-20-03$ & $\mathrm{Fe}$ & .1 & .1 & - & 11 & $<.06$ & 1.5 & 30 \\
\hline \multirow[t]{3}{*}{ MW1-6 } & $09-17-96$ & $\mathrm{~S}$ & 1.1 & .0 & 33 & - & 1.2 & 1.2 & 30 \\
\hline & $04-16-97$ & $\mathrm{Fe} / \mathrm{S}$ & .5 & .0 & - & - & .07 & - & 36 \\
\hline & $10-08-98$ & $\mathrm{Fe}$ & .2 & .0 & - & - & - & 1.1 & 32 \\
\hline
\end{tabular}


Table 2. Predominant redox conditions and ground-water geochemical data collected at Operable Unit 1, Naval Undersea Warfare Center, Division Keyport, Washington, 1996 to 2003-Continued

[All data except those shaded were published previously in Dinicola and others (2002), Dinicola (2003 and 2004). 2002 dissolved methane and carbon dioxide concentrations were collected and analyzed in duplicate. Predominant redox conditions: A, aerobic; Fe, iron reducing; M, methanogenic; Mn, manganese reducing; S, sulfate reducing. Abbreviations: $\mathrm{nM}$, nanomolar; $\mathrm{mg} / \mathrm{L}$, milligram per liter; $\mu \mathrm{S} / \mathrm{cm}$, microsiemen per centimeter at $25^{\circ} \mathrm{Celsius;} \mathrm{mV}$, millivolt; ORP, oxygen reduction potential. Symbols: <, actual value is less than value shown; >, actual value is greater than value shown; -, not analyzed]

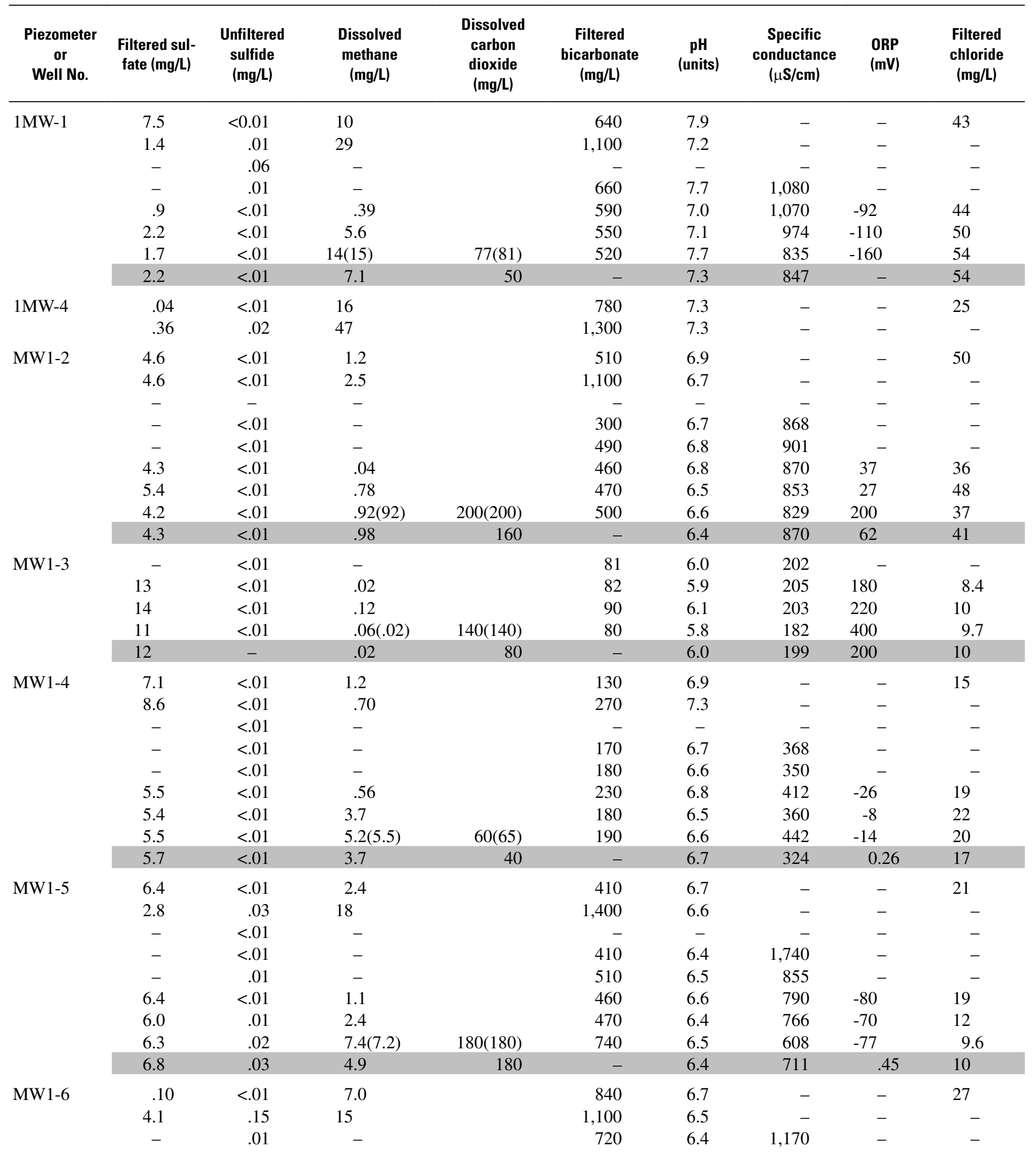


Table 2. Predominant redox conditions and ground-water geochemical data collected at Operable Unit 1, Naval Undersea Warfare Center, Division Keyport, Washington, 1996 to 2003—Continued

[All data except those shaded were published previously in Dinicola and others (2002), Dinicola (2003 and 2004). 2002 dissolved methane and carbon dioxide concentrations were collected and analyzed in duplicate. Predominant redox conditions: A, aerobic; Fe, iron reducing; M, methanogenic; Mn, manganese reducing; S, sulfate reducing. Abbreviations: $\mathrm{nM}$, nanomolar; $\mathrm{mg} / \mathrm{L}$, milligram per liter; $\mu \mathrm{S} / \mathrm{cm}$, microsiemen per centimeter at $25^{\circ} \mathrm{Celsius;} \mathrm{mV}$, millivolt; ORP, oxygen reduction potential. Symbols: <, actual value is less than value shown; >, actual value is greater than value shown; -, not analyzed]

\begin{tabular}{|c|c|c|c|c|c|c|c|c|c|}
\hline $\begin{array}{c}\text { Piezometer } \\
\text { or } \\
\text { Well No. }\end{array}$ & $\begin{array}{c}\text { Date } \\
\text { sampled }\end{array}$ & $\begin{array}{c}\text { Predominant } \\
\text { redox } \\
\text { condition }\end{array}$ & $\begin{array}{l}\text { Dissolved } \\
\text { hydrogen } \\
\text { (nM) }\end{array}$ & $\begin{array}{c}\text { Dissolved } \\
\text { oxygen } \\
\text { (mg/L) }\end{array}$ & $\begin{array}{c}\text { Unfiltered } \\
\text { (total) organic } \\
\text { carbon (mg/L) }\end{array}$ & $\begin{array}{c}\text { Filtered } \\
\text { (dissolved) } \\
\text { organic } \\
\text { carbon (mg/L) }\end{array}$ & $\begin{array}{c}\text { Filtered } \\
\text { nitrate } \\
\text { +nitrite } \\
\text { (mg/L as } \mathrm{N})\end{array}$ & $\begin{array}{c}\text { Filtered } \\
\text { manganese } \\
(\mathrm{mg} / \mathrm{L})\end{array}$ & $\begin{array}{c}\text { Filtered } \\
\text { iron (II) } \\
\text { (mg/L) }\end{array}$ \\
\hline \multirow[t]{5}{*}{ MW1-14 } & $09-17-96$ & $\mathrm{Fe}$ & 0.6 & 0.0 & 42 & - & $<0.02$ & 2.0 & 67 \\
\hline & 04-16-97 & $\mathrm{Fe}$ & .7 & .0 & - & - & .05 & - & 78 \\
\hline & 03-04-98 & $\mathrm{Fe} / \mathrm{S}$ & - & .1 & 36 & - & - & 11 & 68 \\
\hline & $10-07-98$ & $S$ & 1.2 & .0 & - & - & - & 1.5 & 48 \\
\hline & 06-09-99 & $\mathrm{S}$ & 1.0 & .3 & - & - & - & .30 & 57 \\
\hline \multirow[t]{4}{*}{ MW1-15 } & $09-16-96$ & $\mathrm{Fe}$ & .2 & .0 & 50 & - & $<.02$ & 5.7 & 68 \\
\hline & 04-16-97 & $\mathrm{Fe} / \mathrm{S}$ & .8 & .0 & - & - & $<.02$ & - & 77 \\
\hline & $03-05-98$ & S & 1.2 & .0 & 33 & - & - & 18 & 51 \\
\hline & $10-09-98$ & $S$ & 2.9 & .0 & - & - & - & 5.8 & 64 \\
\hline \multirow[t]{9}{*}{ MW1-16 } & $09-17-96$ & $S$ & 2.1 & .0 & 480 & - & $<.02$ & 3.9 & 130 \\
\hline & $04-16-97$ & $\mathrm{Fe} / \mathrm{S}$ & .8 & .0 & - & - & $<.02$ & - & 120 \\
\hline & 03-04-98 & $\mathrm{Fe}$ & .7 & .3 & 350 & - & - & 18 & 100 \\
\hline & $10-08-98$ & M & 9.6 & .0 & - & - & - & 5.4 & 180 \\
\hline & 06-07-99 & M & 6.8 & .6 & - & - & - & $>5$ & 140 \\
\hline & $06-22-00$ & $S$ & - & .1 & 61 & - & - & 1.9 & 60 \\
\hline & 06-14-01 & $S$ & 1.7 & .2 & 64 & 66 & .33 & 2.4 & 56 \\
\hline & $06-13-02$ & M & $4.6-7.6$ & .9 & 71 & - & $<.05$ & 3.2 & 38 \\
\hline & $06-20-03$ & $\mathrm{~S}$ & 2.2 & .2 & - & 29 & $<.06$ & 2.1 & 37 \\
\hline \multirow[t]{5}{*}{ MW1-17 } & $09-17-96$ & $\mathrm{Fe}$ & .7 & .0 & 23 & - & $<.02$ & 1.3 & 62 \\
\hline & $04-16-97$ & $\mathrm{Fe}$ & .6 & .0 & - & - & $<.02$ & - & 37 \\
\hline & $10-09-98$ & $\mathrm{Fe}$ & - & .0 & - & - & - & .80 & 56 \\
\hline & $06-22-00$ & $\mathrm{~S}$ & 1.2 & .0 & 11 & - & - & 1.2 & 68 \\
\hline & $06-12-01$ & $\mathrm{~S}$ & $2.0-2.7$ & .4 & 9.2 & 8.0 & $<.05$ & 1.2 & 48 \\
\hline \multirow[t]{3}{*}{ MW1-18 } & $09-17-96$ & $\mathrm{Fe} / \mathrm{S}$ & 1.0 & .0 & 28 & - & $<.02$ & 4.0 & 12 \\
\hline & $04-16-97$ & $\mathrm{Fe}$ & .5 & .0 & - & - & .05 & - & 23 \\
\hline & $10-07-98$ & $\mathrm{Fe}$ & - & .2 & - & - & - & .77 & 3.3 \\
\hline \multirow[t]{5}{*}{ MW1-20 } & 06-08-99 & $\mathrm{Fe}$ & .9 & .3 & - & - & - & .35 & .03 \\
\hline & $06-21-00$ & $\mathrm{Fe}$ & .4 & .0 & 2.2 & - & $<.05$ & .24 & .11 \\
\hline & 06-13-01 & $\mathrm{S}$ & 2.1 & .2 & 3.0 & 1.4 & $<.05$ & .28 & .01 \\
\hline & $06-12-02$ & An & $>100$ & .1 & 1.4 & - & $<.05$ & .16 & .01 \\
\hline & 06-17-03 & $\mathrm{Fe}$ & .5 & .2 & - & 1.7 & $<.06$ & .24 & .05 \\
\hline \multirow[t]{8}{*}{ MW1-25 } & $09-17-96$ & $\mathrm{Fe}$ & .4 & 2.7 & 7.4 & - & .14 & .16 & .74 \\
\hline & $04-17-97$ & $\mathrm{Fe}$ & .8 & .1 & - & - & $<.02$ & - & .88 \\
\hline & $03-05-98$ & $\mathrm{Fe}$ & .3 & .3 & 7.9 & - & - & .20 & .73 \\
\hline & $10-05-98$ & $\mathrm{Fe}$ & .2 & .1 & - & - & - & .19 & .99 \\
\hline & $06-22-00$ & $\mathrm{Fe}$ & .4 & .2 & 6.5 & - & - & .16 & .80 \\
\hline & $06-12-01$ & $S$ & $2.8-4.3$ & .2 & 7.1 & 6.8 & $<.05$ & .16 & .99 \\
\hline & $06-14-02$ & $S$ & $0.7-2.4$ & .1 & 6.2 & - & $<.05$ & .18 & 1.1 \\
\hline & 06-19-03 & $\mathrm{Fe}$ & .3 & .1 & - & 6.5 & $<.06$ & .18 & 1.1 \\
\hline \multirow[t]{5}{*}{ MW1-28 } & $09-16-96$ & $\mathrm{Fe}$ & .3 & 2.1 & 7.2 & - & $<.02$ & .20 & 1.0 \\
\hline & $04-17-97$ & $\mathrm{Fe}$ & 1.0 & .0 & - & - & .04 & - & .99 \\
\hline & $03-05-98$ & $\mathrm{Fe}$ & .4 & .5 & 7.7 & - & - & .20 & .67 \\
\hline & $10-07-98$ & $\mathrm{Fe}$ & .6 & .0 & - & - & - & .19 & 1.0 \\
\hline & $06-22-00$ & $\mathrm{Fe}$ & .3 & .0 & 13 & - & - & .16 & .66 \\
\hline
\end{tabular}


Table 2. Predominant redox conditions and ground-water geochemical data collected at Operable Unit 1, Naval Undersea Warfare Center, Division Keyport, Washington, 1996 to 2003-Continued

[All data except those shaded were published previously in Dinicola and others (2002), Dinicola (2003 and 2004). 2002 dissolved methane and carbon dioxide concentrations were collected and analyzed in duplicate. Predominant redox conditions: A, aerobic; Fe, iron reducing; M, methanogenic; Mn, manganese reducing; S, sulfate reducing. Abbreviations: $\mathrm{nM}$, nanomolar; $\mathrm{mg} / \mathrm{L}$, milligram per liter; $\mu \mathrm{S} / \mathrm{cm}$, microsiemen per centimeter at $25^{\circ} \mathrm{Celsius;} \mathrm{mV}$, millivolt; ORP, oxygen reduction potential. Symbols: <, actual value is less than value shown; >, actual value is greater than value shown; -, not analyzed]

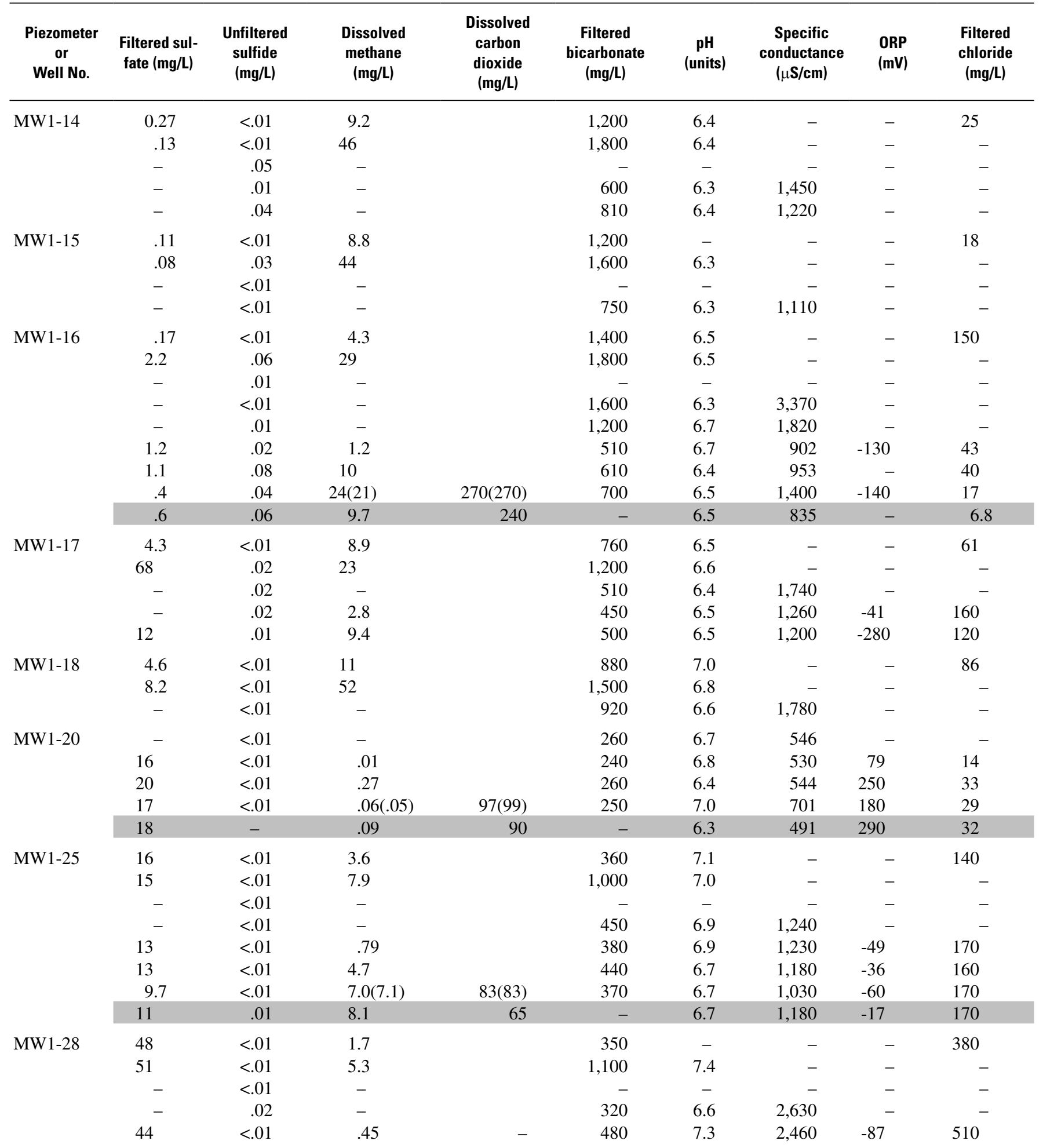


Table 2. Predominant redox conditions and ground-water geochemical data collected at Operable Unit 1, Naval Undersea Warfare Center, Division Keyport, Washington, 1996 to 2003—Continued

[All data except those shaded were published previously in Dinicola and others (2002), Dinicola (2003 and 2004). 2002 dissolved methane and carbon dioxide concentrations were collected and analyzed in duplicate. Predominant redox conditions: A, aerobic; Fe, iron reducing; M, methanogenic; Mn, manganese reducing; S, sulfate reducing. Abbreviations: $\mathrm{nM}$, nanomolar; $\mathrm{mg} / \mathrm{L}$, milligram per liter; $\mu \mathrm{S} / \mathrm{cm}$, microsiemen per centimeter at $25^{\circ} \mathrm{Celsius;} \mathrm{mV}$, millivolt; ORP, oxygen reduction potential. Symbols: <, actual value is less than value shown; >, actual value is greater than value shown; -, not analyzed]

\begin{tabular}{|c|c|c|c|c|c|c|c|c|c|}
\hline $\begin{array}{c}\text { Piezometer } \\
\text { or } \\
\text { Well No. }\end{array}$ & $\begin{array}{c}\text { Date } \\
\text { sampled }\end{array}$ & $\begin{array}{c}\text { Predominant } \\
\text { redox } \\
\text { condition }\end{array}$ & $\begin{array}{l}\text { Dissolved } \\
\text { hydrogen } \\
\text { (nM) }\end{array}$ & $\begin{array}{l}\text { Dissolved } \\
\text { oxygen } \\
\text { (mg/L) }\end{array}$ & $\begin{array}{c}\text { Unfiltered } \\
\text { (total) organic } \\
\text { carbon (mg/L) }\end{array}$ & $\begin{array}{c}\text { Filtered } \\
\text { (dissolved) } \\
\text { organic } \\
\text { carbon (mg/L) }\end{array}$ & $\begin{array}{c}\text { Filtered } \\
\text { nitrate } \\
\text { +nitrite } \\
\text { (mg/L as N) }\end{array}$ & $\begin{array}{c}\text { Filtered } \\
\text { manganese } \\
(\mathrm{mg} / \mathrm{L})\end{array}$ & $\begin{array}{l}\text { Filtered } \\
\text { iron (II) } \\
(\mathrm{mg} / \mathrm{L})\end{array}$ \\
\hline \multirow{3}{*}{$\begin{array}{l}\text { MW1-28 } \\
\text { (Continued) }\end{array}$} & $06-12-01$ & $\mathrm{~S} / \mathrm{M}$ & $4.1-5.7$ & 0.5 & 10 & 6.9 & $<0.05$ & 0.16 & 0.90 \\
\hline & $06-14-02$ & An & $>100$ & .1 & 7.0 & - & $<.05$ & .16 & .92 \\
\hline & $06-19-03$ & $\mathrm{~S}$ & 2.5 & .1 & - & 6.8 & $<.06$ & .16 & .66 \\
\hline \multirow[t]{2}{*}{ MW1-29 } & $09-16-96$ & $\mathrm{Mn} / \mathrm{Fe}$ & .0 & 1.9 & - & - & $<.02$ & .86 & 2.0 \\
\hline & $04-17-97$ & $\mathrm{Fe}$ & .7 & .0 & - & - & .29 & - & 2.1 \\
\hline MW1-31 & $09-16-96$ & $\mathrm{Mn} / \mathrm{Fe}$ & - & - & 5.6 & - & - & 3.6 & .32 \\
\hline \multirow[t]{4}{*}{ MW1-32 } & 09-16-96 & $\mathrm{Fe}$ & .4 & 2.7 & .8 & - & 0.07 & 0.23 & 1.3 \\
\hline & 04-17-97 & $\mathrm{Fe}$ & - & 1.2 & - & - & .17 & - & .87 \\
\hline & $03-02-98$ & $\mathrm{Fe}$ & - & $<1.0$ & - & - & - & .10 & 1.1 \\
\hline & $10-05-98$ & $\mathrm{Fe}$ & .1 & .0 & - & - & - & .36 & 1.0 \\
\hline \multirow[t]{5}{*}{ MW1-33 } & $10-07-98$ & A & - & 3.3 & .1 & - & - & .003 & $<.01$ \\
\hline & $06-21-00$ & A & - & 3.8 & .7 & - & 1.3 & $<.002$ & $<.01$ \\
\hline & $06-11-01$ & A & - & 3.8 & 1.5 & 1.4 & 1.1 & $<.003$ & $<.01$ \\
\hline & $06-10-02$ & A & - & 3.4 & 1.2 & - & 1.1 & $<.002$ & $<.01$ \\
\hline & $06-17-03$ & A & - & 3.0 & - & .7 & .98 & $<.004$ & $<.01$ \\
\hline \multirow[t]{3}{*}{ MW1-35 } & $10-07-98$ & A & - & 2.4 & 1.9 & - & - & .15 & $<.01$ \\
\hline & 06-08-99 & A & - & 2.1 & - & - & - & - & - \\
\hline & $06-20-00$ & A & - & 3.0 & 2.2 & - & .16 & $<.002$ & $<.01$ \\
\hline \multirow[t]{2}{*}{ MW1-36 } & $10-09-98$ & $\mathrm{Fe}$ & - & .0 & - & - & - & .30 & 3.6 \\
\hline & $06-20-00$ & $\mathrm{Fe}$ & .5 & .1 & 2.4 & - & $<.05$ & .28 & 3.2 \\
\hline \multirow[t]{6}{*}{ MW1-37 } & 09-16-96 & $\mathrm{Fe}$ & .8 & 1.5 & 6.9 & - & $<.02$ & .12 & .48 \\
\hline & 04-17-97 & S & 3.3 & .0 & - & - & $<.02$ & - & .80 \\
\hline & 03-03-98 & $\mathrm{Fe}$ & .4 & .4 & 5.7 & - & - & .10 & .86 \\
\hline & $10-09-98$ & $\mathrm{Fe}$ & .4 & .0 & - & - & - & $<.01$ & .43 \\
\hline & 06-07-99 & $\mathrm{Fe}$ & .4 & .4 & - & - & - & .10 & .32 \\
\hline & $06-20-00$ & $\mathrm{Fe}$ & .1 & .1 & 5.8 & - & $<.05$ & .13 & .25 \\
\hline \multirow[t]{3}{*}{ MW1-38 } & $10-09-98$ & $\mathrm{Fe}$ & - & .1 & - & - & - & .20 & .08 \\
\hline & $06-20-00$ & $\mathrm{Fe}$ & .1 & .2 & 5.6 & - & $<.05$ & .08 & .10 \\
\hline & $06-12-02$ & S & 1.4 & .0 & 5.0 & - & $<.05$ & .08 & 0.42 \\
\hline \multirow[t]{9}{*}{ MW1-39 } & 09-16-96 & $\mathrm{Fe} / \mathrm{S}$ & .6 & 2.0 & 4.4 & - & $<.02$ & .02 & $<.01$ \\
\hline & 04-17-97 & $\mathrm{S}$ & 4.5 & .0 & - & - & $<.02$ & - & .05 \\
\hline & 03-03-98 & $\mathrm{Fe} / \mathrm{S}$ & .3 & .3 & 3.7 & - & - & .10 & .03 \\
\hline & $10-09-98$ & $\mathrm{Fe} / \mathrm{S}$ & .5 & .0 & - & - & - & $<.01$ & .04 \\
\hline & 06-07-99 & $\mathrm{Fe} / \mathrm{S}$ & 1.0 & .3 & - & - & - & .10 & .02 \\
\hline & $06-20-00$ & $\mathrm{Fe} / \mathrm{S}$ & .5 & .1 & 2.4 & - & $<.05$ & .01 & .07 \\
\hline & $06-12-01$ & S & 1.4 & .3 & 3.4 & 3.3 & $<.05$ & .01 & $<.01$ \\
\hline & $06-12-02$ & M & $>30$ & .0 & 2.8 & - & $<.05$ & .01 & 0.1 \\
\hline & 06-19-03 & S & 1.8 & .1 & - & 2.5 & $<.06$ & .01 & $<.01$ \\
\hline \multirow[t]{3}{*}{ MW1-41 } & 06-09-99 & S & 1.0 & 0.3 & - & - & - & 2.2 & 60 \\
\hline & $06-21-00$ & $S$ & 1.2 & .1 & 22 & - & $<.05$ & 3.5 & 55 \\
\hline & $06-11-01$ & S & 2.0 & .3 & 14 & 14 & $<.05$ & 3.7 & 66 \\
\hline
\end{tabular}


Table 2. Predominant redox conditions and ground-water geochemical data collected at Operable Unit 1, Naval Undersea Warfare Center, Division Keyport, Washington, 1996 to 2003-Continued

[All data except those shaded were published previously in Dinicola and others (2002), Dinicola (2003 and 2004). 2002 dissolved methane and carbon dioxide concentrations were collected and analyzed in duplicate. Predominant redox conditions: A, aerobic; Fe, iron reducing; M, methanogenic; Mn, manganese reducing; S, sulfate reducing. Abbreviations: $\mathrm{nM}$, nanomolar; $\mathrm{mg} / \mathrm{L}$, milligram per liter; $\mu \mathrm{S} / \mathrm{cm}$, microsiemen per centimeter at $25^{\circ} \mathrm{Celsius;} \mathrm{mV}$, millivolt; ORP, oxygen reduction potential. Symbols: <, actual value is less than value shown; >, actual value is greater than value shown; -, not analyzed]

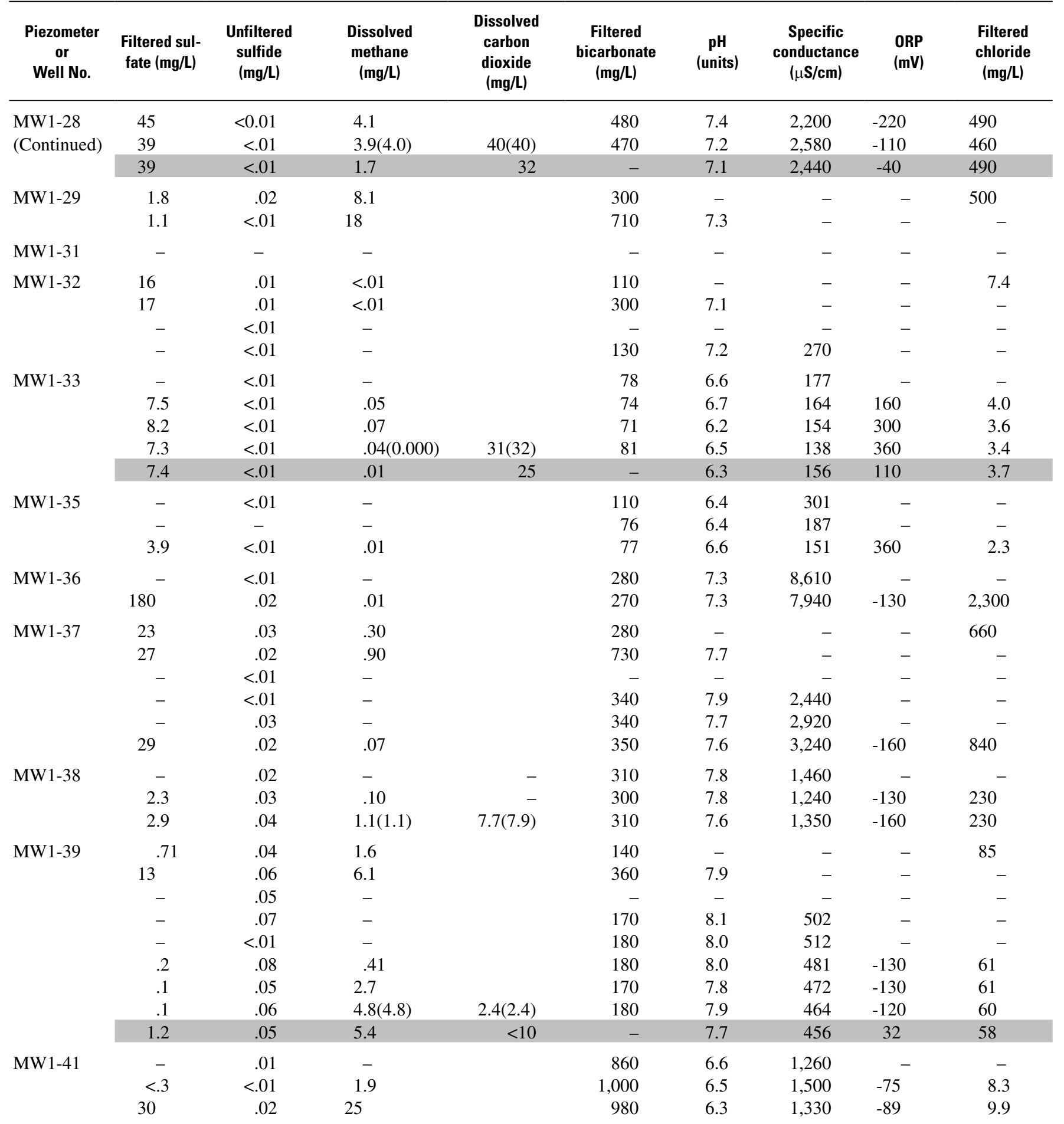


Table 2. Predominant redox conditions and ground-water geochemical data collected at Operable Unit 1, Naval Undersea Warfare Center, Division Keyport, Washington, 1996 to 2003—Continued

[All data except those shaded were published previously in Dinicola and others (2002), Dinicola (2003 and 2004). 2002 dissolved methane and carbon dioxide concentrations were collected and analyzed in duplicate. Predominant redox conditions: A, aerobic; Fe, iron reducing; M, methanogenic; Mn, manganese reducing; S, sulfate reducing. Abbreviations: $\mathrm{nM}$, nanomolar; $\mathrm{mg} / \mathrm{L}$, milligram per liter; $\mu \mathrm{S} / \mathrm{cm}$, microsiemen per centimeter at $25^{\circ} \mathrm{Celsius;} \mathrm{mV}$, millivolt; ORP, oxygen reduction potential. Symbols: <, actual value is less than value shown; >, actual value is greater than value shown; -, not analyzed]

\begin{tabular}{|c|c|c|c|c|c|c|c|c|c|}
\hline $\begin{array}{c}\text { Piezometer } \\
\text { or } \\
\text { Well No. }\end{array}$ & $\begin{array}{c}\text { Date } \\
\text { sampled }\end{array}$ & $\begin{array}{c}\text { Predominant } \\
\text { redox } \\
\text { condition }\end{array}$ & $\begin{array}{l}\text { Dissolved } \\
\text { hydrogen } \\
\text { (nM) }\end{array}$ & $\begin{array}{l}\text { Dissolved } \\
\text { oxygen } \\
\text { (mg/L) }\end{array}$ & $\begin{array}{c}\text { Unfiltered } \\
\text { (total) organic } \\
\text { carbon (mg/L) }\end{array}$ & $\begin{array}{c}\text { Filtered } \\
\text { (dissolved) } \\
\text { organic } \\
\text { carbon (mg/L) }\end{array}$ & $\begin{array}{c}\text { Filtered } \\
\text { nitrate } \\
\text { +nitrite } \\
\text { (mg/L as N) }\end{array}$ & $\begin{array}{c}\text { Filtered } \\
\text { manganese } \\
(\mathrm{mg} / \mathrm{L})\end{array}$ & $\begin{array}{c}\text { Filtered } \\
\text { iron (II) } \\
(\mathrm{mg} / \mathrm{L})\end{array}$ \\
\hline \multirow{3}{*}{$\begin{array}{l}\text { MW1-41 } \\
\text { (Continued) } \\
\text { (dup) }\end{array}$} & 06-10-02 & $\mathrm{S}$ & 2.2 & .8 & 20 & - & $<.05$ & 3.6 & 52 \\
\hline & 06-18-03 & $\mathrm{S}$ & 1.9 & .0 & - & 19 & $<.06$ & 3.9 & 50 \\
\hline & $06-18-03$ & S & - & - & - & - & $<.06$ & 4.0 & 48 \\
\hline \multirow[t]{3}{*}{ P1-1 } & 06-09-99 & $\mathrm{Fe}$ & .7 & .4 & - & - & - & 4.0 & 59 \\
\hline & 06-11-02 & $\mathrm{S}$ & 1.4 & .0 & 17 & - & $<.05$ & 2.7 & 40 \\
\hline & $06-18-03$ & $\mathrm{~S}$ & 1.5 & .0 & - & 18 & $<.06$ & 3.4 & 32 \\
\hline \multirow[t]{3}{*}{ P1-3 } & 06-09-99 & $\mathrm{Fe}$ & .4 & .2 & - & - & - & 1.0 & 19 \\
\hline & $06-11-02$ & $\mathrm{Fe}$ & .3 & .0 & 45 & - & $<.05$ & 2.6 & 39 \\
\hline & $06-18-03$ & $\mathrm{Fe}$ & .3 & .1 & - & 19 & $<.06$ & 2.0 & 29 \\
\hline \multirow{2}{*}{ P1-4 } & 06-09-99 & $\mathrm{Fe}$ & .7 & .3 & - & - & - & 0.34 & 2.6 \\
\hline & $06-13-01$ & $\mathrm{Fe}$ & .1 & .5 & 9.8 & 8.7 & $<.05$ & .38 & 3.4 \\
\hline \multirow[t]{3}{*}{ (dup) } & 06-13-01 & $\mathrm{Fe}$ & - & - & 8.4 & 6.2 & $<.05$ & .38 & 3.6 \\
\hline & $06-11-02$ & $\mathrm{Fe}$ & .2 & .1 & 8.0 & - & $<.05$ & 2.6 & 3.7 \\
\hline & $06-18-03$ & $\mathrm{Fe}$ & .2 & .1 & - & 7.0 & $<.06$ & .43 & 4.1 \\
\hline \multirow[t]{3}{*}{ P1-5 } & 06-08-99 & S & 3.0 & .3 & - & - & - & 3.1 & 72 \\
\hline & $06-10-02$ & $\mathrm{~S}$ & 1.7 & .1 & 25 & - & $<.05$ & 2.6 & 62 \\
\hline & $06-18-03$ & $\mathrm{~S}$ & 2.2 & .1 & - & 24 & $<.06$ & 3.1 & 54 \\
\hline \multirow[t]{3}{*}{ P1-6 } & 06-08-99 & $S$ & 1.8 & .1 & - & - & - & .12 & .02 \\
\hline & $06-14-01$ & $\mathrm{~S}$ & 1.8 & .2 & 34 & 34 & .23 & .45 & .95 \\
\hline & $06-13-02$ & $\mathrm{~S}$ & 1.6 & .0 & - & 26 & $<.05$ & .88 & 1.0 \\
\hline \multirow{2}{*}{ (dup) } & $06-13-02$ & $S$ & - & - & - & - & $<.05$ & .84 & - \\
\hline & $06-20-03$ & $\mathrm{Fe}$ & .3 & .2 & - & 4.1 & $<.06$ & .08 & .13 \\
\hline \multirow[t]{5}{*}{ P1-7 } & 06-08-99 & $S$ & 1.2 & .1 & - & - & - & .61 & 2.1 \\
\hline & $06-22-00$ & $\mathrm{Mn} / \mathrm{Fe}$ & - & .1 & 19 & - & - & 2.6 & 3.2 \\
\hline & $06-14-01$ & $\mathrm{Mn} / \mathrm{Fe}$ & .2 & .2 & 11 & 11 & $<.05$ & 2.3 & 2.0 \\
\hline & $06-14-02$ & $\mathrm{Mn} / \mathrm{Fe}$ & .2 & 1.3 & 8.9 & - & $<.05$ & 2.2 & 1.9 \\
\hline & $06-20-03$ & $\mathrm{Mn} / \mathrm{Fe}$ & .1 & .1 & - & 5.6 & $<.06$ & 1.9 & 1.3 \\
\hline \multirow[t]{3}{*}{ P1-8 } & 06-07-99 & $S$ & 1.8 & .0 & - & - & - & .20 & .08 \\
\hline & $06-14-01$ & $\mathrm{Fe}$ & .7 & .1 & 4.8 & 4.7 & .06 & .16 & .22 \\
\hline & $06-13-02$ & $\mathrm{Fe}$ & .6 & .3 & 8.8 & - & $<.05$ & .21 & .38 \\
\hline \multirow[t]{2}{*}{ (dup) } & $06-13-02$ & $\mathrm{Fe}$ & - & - & 9.0 & - & $<.05$ & .21 & - \\
\hline & $06-20-03$ & $\mathrm{Fe}$ & .6 & .1 & - & 2.3 & $<.06$ & .09 & .12 \\
\hline \multirow[t]{5}{*}{ P1-9 } & 06-08-99 & M & 19 & .3 & - & - & - & .90 & .03 \\
\hline & $06-22-00$ & $\mathrm{~S} / \mathrm{M}$ & - & .1 & 10 & - & - & .69 & .20 \\
\hline & $06-14-01$ & M & 6.7 & .1 & 2.3 & 1.7 & $<.05$ & .19 & .05 \\
\hline & $06-13-02$ & An & - & .6 & 9.8 & - & $<.05$ & 1.2 & .42 \\
\hline & $06-20-03$ & $\mathrm{Fe}$ & .2 & .1 & - & 3.7 & $<.06$ & .24 & $<.01$ \\
\hline \multirow[t]{5}{*}{ P1-10 } & 06-07-99 & $\mathrm{Fe}$ & .7 & .3 & - & - & - & .10 & .11 \\
\hline & $06-22-00$ & $\mathrm{Fe}$ & - & .0 & 7.2 & - & - & .07 & .25 \\
\hline & $06-13-01$ & S & 2.0 & .2 & 3.0 & 4.2 & $<.05$ & .07 & .20 \\
\hline & $06-12-02$ & $\mathrm{Fe}$ & .3 & .1 & 3.5 & - & $<.05$ & .05 & .41 \\
\hline & 06-19-03 & $\mathrm{Fe}$ & .2 & .1 & - & 3.5 & $<.06$ & .42 & .34 \\
\hline
\end{tabular}


Table 2. Predominant redox conditions and ground-water geochemical data collected at Operable Unit 1, Naval Undersea Warfare Center, Division Keyport, Washington, 1996 to 2003-Continued

[All data except those shaded were published previously in Dinicola and others (2002), Dinicola (2003 and 2004). 2002 dissolved methane and carbon dioxide concentrations were collected and analyzed in duplicate. Predominant redox conditions: A, aerobic; Fe, iron reducing; M, methanogenic; Mn, manganese reducing; S, sulfate reducing. Abbreviations: $\mathrm{nM}$, nanomolar; $\mathrm{mg} / \mathrm{L}$, milligram per liter; $\mu \mathrm{S} / \mathrm{cm}$, microsiemen per centimeter at $25^{\circ} \mathrm{Celsius;} \mathrm{mV}$, millivolt; ORP, oxygen reduction potential. Symbols: <, actual value is less than value shown; >, actual value is greater than value shown; -, not analyzed]

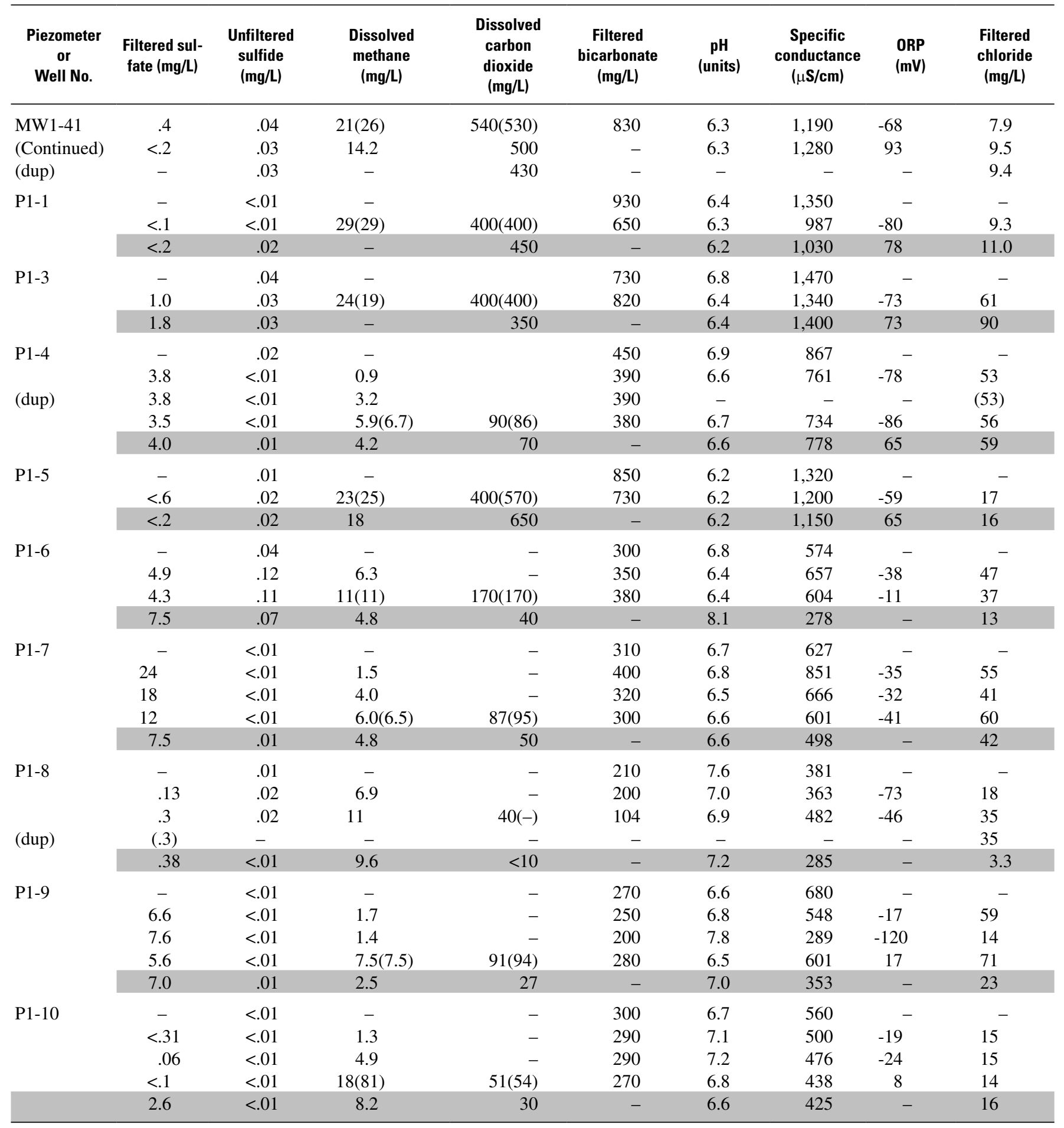




\section{Volatile Organic Compounds}

CVOC data collected by the USGS at OU 1 in June 2003 and earlier (Dinicola and others, 2002; Dinicola 2003; Dinicola, 2004) are shown in table 3 . Complete analytical results, including those for both chlorinated and nonchlorinated VOCs, for June 2003 and previous years are available from the USGS NWIS web site http://waterdata.usgs. gov/wa/nwis/qwdata.

In duplicate samples collected from piezometer P1-5, the CVOC concentrations agreed within 6 percent (table 3 ). A field blank that was performed with the pump at the end of the sampling round showed some carry-over contamination of TCE and cis-DCE resulting in field blank concentrations of 60 and $23 \mu \mathrm{g} / \mathrm{L}$, respectively. The carry over contamination was determined to be the result of reusing the same small piece of flexible tubing (Masterflex ${ }^{\circledR}$ ) needed to run the peristaltic pump. The effect of carry-over contamination on the reported data was not substantial because the three pumps used at OU 1 were first used to sample the least contaminated wells and then later used at the end of the field trip to sample the more contaminated wells. This conclusion is supported by low or non-detectable concentrations of CVOC measured at sites P1-1, P1-3, P1-5, and MW1-39 that all had historically low or non-detectable CVOC concentrations. For future sampling at the site, a new clean piece of Masterflex ${ }^{\circledR}$ tubing will be used at each well or piezometer to eliminate the potential for carryover contamination. The polyurethane tubing that is lowered into the wells for sampling has been discarded after a single use during all prior sampling rounds.

Compared to 2002 data, total CVOC concentrations were nearly unchanged in all northern plantation piezometers sampled (P1-1 through P1-5), although the concentrations were historically low at two of those sites. Total CVOC concentrations decreased in all southern plantation samples
(P1-6 through P1-10). Compared to 2002 data, total CVOC concentrations in 2003 were lower in all southern plantation piezometers sampled, and the lowest concentrations of the project record were observed in P1-6, P1-8, and P1-10. There was an extremely large reduction in concentrations of CVOCs in P1-8 - from 32,000 $\mu \mathrm{g} / \mathrm{L}$ in June 2002 down to 270 $\mu \mathrm{g} / \mathrm{L}$ in June 2003 . Scrutiny of the field notes and sampling documentation for P1-8 did not indicate any errors in sample handling. Special attention will be directed during the planned June 2004 sampling to confirm or refute this dramatic change. Observed decreases in CVOC concentrations appear to be in contrast with the 2003 redox data that suggested less favorable conditions for reductive dechlorination. Again, the Navy and USGS have plans in place to do more extensive datacollection and interpretation during 2004 to better understand and document possible changes in redox conditions and contaminant biodegradation.

\section{June 2004 Sampling}

The only change in standard sampling procedures proposed for June 2004 is to use a new clean piece of Masterflex ${ }^{\circledR}$ tubing at each well or piezometer to eliminate the potential for carry-over contamination. In addition to usual annual sampling, the more frequent collection and analysis of samples from those wells previously sampled and from additional wells would enable a better characterization of redox conditions and contaminant distribution and transport throughout the site. Sampling (with passivediffusion or similar methods) and analysis of shallow ground water discharging to the marsh would allow calculation of contaminant mass fluxes and loss rates, and comparison of these factors with conditions in 2000. 
Table 3. Concentrations of selected chlorinated volatile organic compounds in ground water from piezometers and monitoring wells sampled by the U.S. Geological Survey at Operable Unit 1, Naval Undersea Warfare Center, Division Keyport, Washington, 1999 to 2003

[All data except those shaded were published previously in Dinicola and others (2002). Chlorinated volatile organic compounds (CVOCs): PCE, tetrachloroethene; TCE, trichloroethene; cis-DCE, cis-1,2-dichloroethene; trans-DCE, -1,2-dichloroethene; VC, vinyl chloride; TCA, 1,1,1-trichloroethane; 1,1-DCA, 1,1-dichloroethane; CA, chloroethane; 1,1-DCE, 1,1-dichloroethene; BTEX, benzene, toluene, ethylbenzene, and xylene; CVOCs, chlorinated volatile organic compounds. Abbreviations: $\mu \mathrm{g} / \mathrm{L}$, microgram per liter; dup, duplicate. Symbols: <, actual value is less than value shown; nd, not detected]

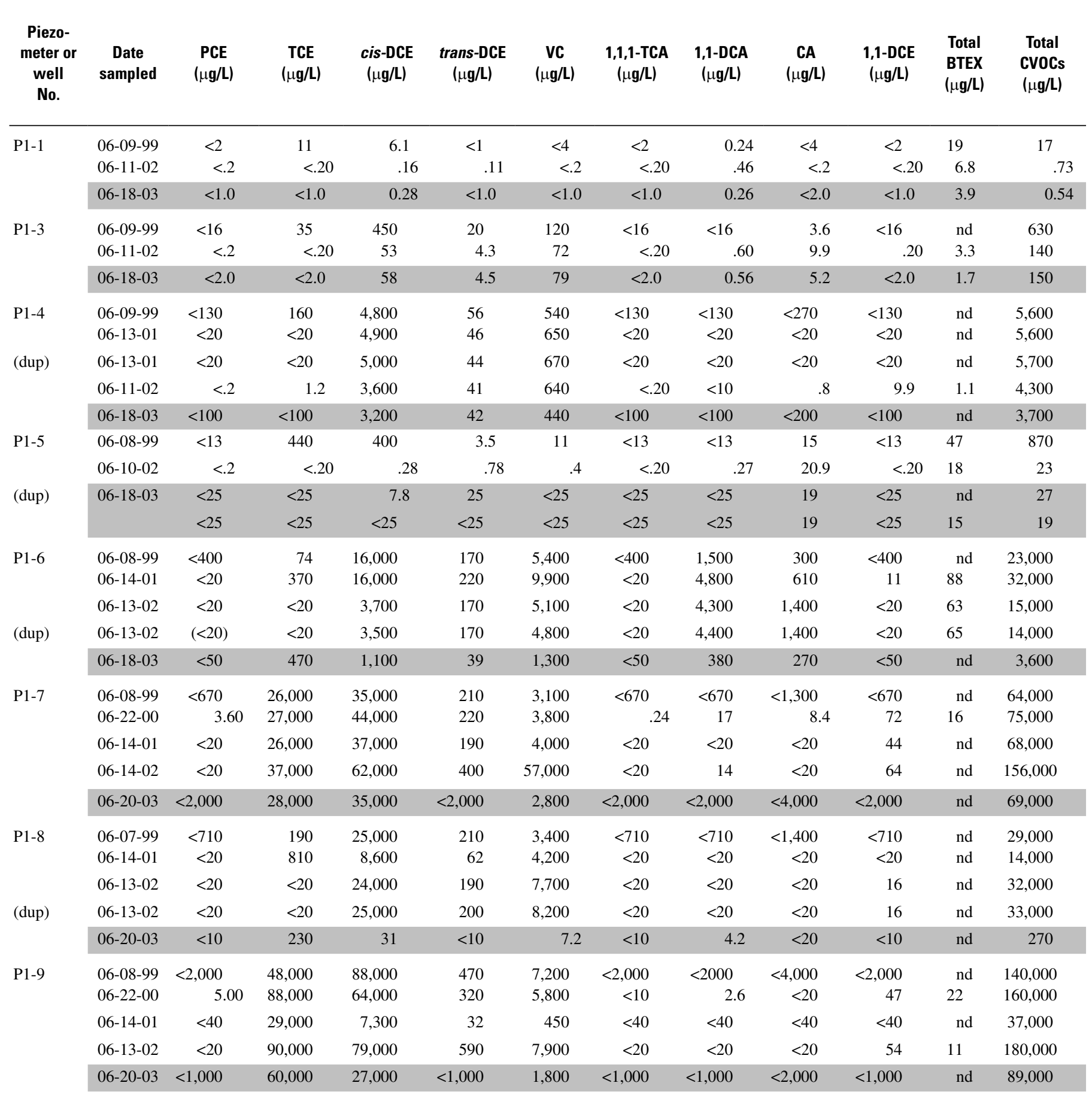


Table 3. Concentrations of selected chlorinated volatile organic compounds in ground water from piezometers and monitoring wells sampled by the U.S. Geological Survey at Operable Unit 1, Naval Undersea Warfare Center, Division Keyport, Washington, 1999 to 2003 —Continued

[All data except those shaded were published previously in Dinicola and others (2002). Chlorinated volatile organic compounds (CVOCs): PCE, tetrachloroethene; TCE, trichloroethene; cis-DCE, cis-1,2-dichloroethene; trans-DCE, -1,2-dichloroethene; VC, vinyl chloride; TCA, 1,1,1-trichloroethane; 1,1-DCA, 1,1-dichloroethane; CA, chloroethane; 1,1-DCE, 1,1-dichloroethene; BTEX, benzene, toluene, ethylbenzene, and xylene; CVOCs, chlorinated volatile organic compounds. Abbreviations: $\mu \mathrm{g} / \mathrm{L}$, microgram per liter; dup, duplicate. Symbols: <, actual value is less than value shown; nd, not detected]

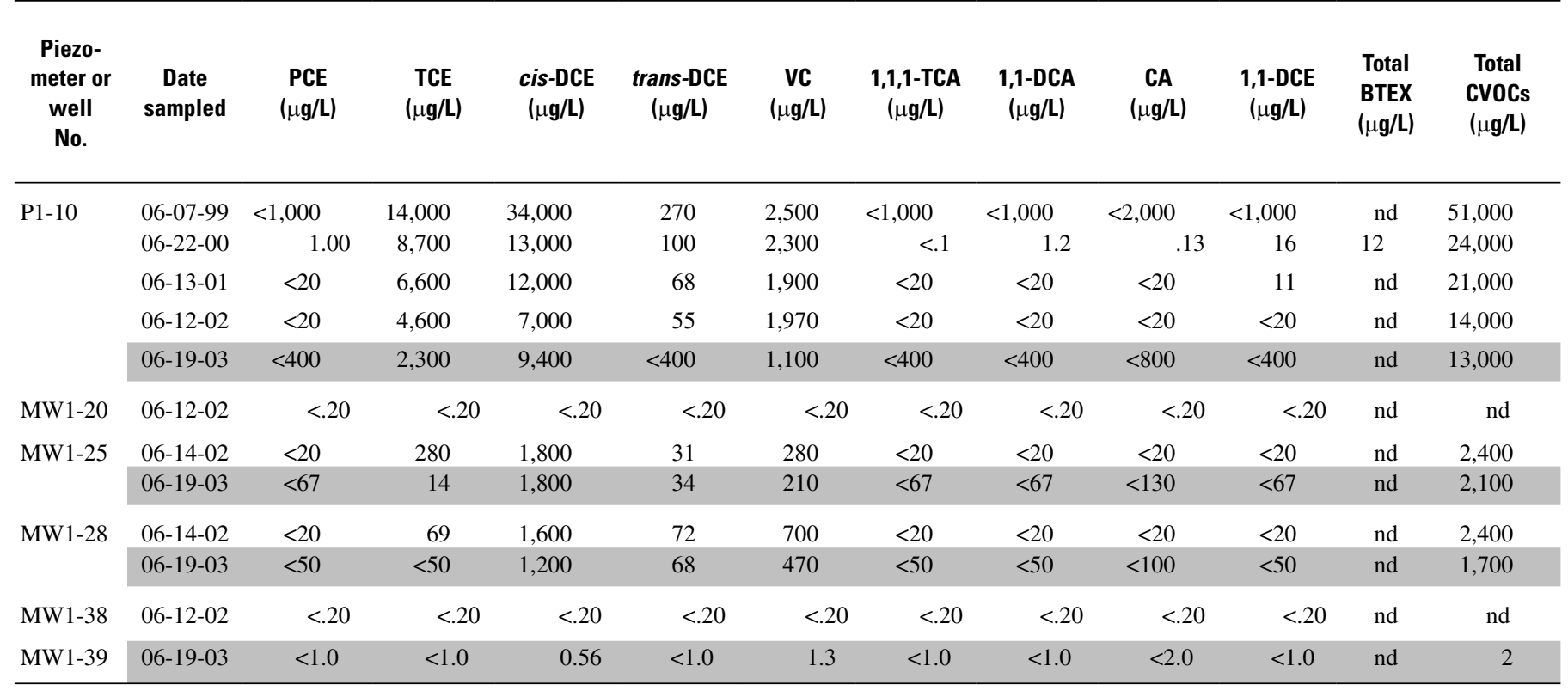

\section{Summary}

Previous investigations have shown that natural attenuation and biodegradation of chlorinated volatile organic compounds (CVOCs) are substantial in shallow ground water beneath the 9-acre former landfill at Operable Unit 1 (OU 1), Naval Undersea Warfare Center (NUWC), Division Keyport, Washington. The U.S. Geological Survey (USGS) has continued to monitor ground-water geochemistry to assure that conditions remain favorable for contaminant biodegradation. This report presents the ground-water geochemical and selected CVOC data collected at OU 1 by the USGS during June 17-20, 2003 in support of long-term monitoring for natural attenuation.

Strongly reducing conditions most favorable for reductive dechlorination of CVOCs were found in fewer upperaquifer wells in June 2003 than were found during sampling periods in 2001 and 2002. Redox conditions in water from the intermediate aquifer just downgradient from the landfill remained somewhat favorable for reductive dechlorination. As was noted in previous monitoring reports, the changes in redox conditions observed at individual wells have not been consistent or substantial throughout either the upper or the intermediate aquifers. The June 2003 data support the hypothesis that the downhole deployment of a data sonde during purging of wells in 2002 resulted in non-representative concentrations of dissolved $\mathrm{H}_{2}$ at some wells. The data sonde was not deployed downhole while purging any wells in June 2003 , and previously reported high concentrations (>20 nM) of $\mathrm{H}_{2}$ in wells all decreased to concentrations similar to pre2002 historical data.

Compared to 2002 data, total CVOC concentrations in June 2003 were nearly unchanged in all northern plantation piezometers sampled, although the concentrations were historically low at two of those sites. Total CVOC concentrations decreased consistently in all southern plantation samples. Historically low total CVOC concentrations were observed in three of the piezometers sampled, and a two order-of-magnitude decrease in total CVOCs was observed at one of those sites. The observed decreases in CVOC concentrations appear to be in contrast with the 2003 redox data that suggested less favorable conditions for reductive dechlorination. The Navy and USGS plan to do more extensive data-collection and interpretation during 2004 to better understand and document possible changes in redox conditions and contaminant biodegradation. 


\section{References Cited}

Bradley, P.M, Landmeyer, J.E., and Dinicola, R.S., 1998, Anaerobic oxidation of [1,2-14C] dichloroethene under Mn(IV)-reducing conditions: Applied and Environmental Microbiology, v. 64, no. 4, p. 1560-1562.

Chapelle, F.H., Vroblesky, D.A., Woodward, J.C., and Lovely, D.R., 1997, Practical considerations for measuring hydrogen concentrations in groundwater: Environmental Science and Technology, v. 31, no. 10, p. 2873-2877.

Dinicola, R.S., 2003, Natural attenuation monitoring data, Naval Undersea Warfare Center, Division Keyport, Washington, June 2001: U.S. Geological Survey Open-File Report 03-344, 17 p.

Dinicola, R.S., 2004, Natural attenuation monitoring data, Operable Unit 1, Naval Undersea Warfare Center, Division Keyport, Washington, June 2002: U.S. Geological Survey Open-File Report 2004-1203, 19 p.

Dinicola, R.S., S.E. Cox, J.E. Landmeyer, and P.M. Bradley, 2002, Natural attenuation of chlorinated volatile organic compounds in ground water at Operable Unit 1, Naval Undersea Weapons Center, Division Keyport, Washington: U.S. Geological Survey Water-Resources Investigations Report 02-4119, 118 p.

Fishman, M.J., ed., 1993, Methods of analysis by the U.S. Geological Survey National Water Quality LaboratoryDetermination of inorganic and organic constituents in water and fluvial sediments: U.S. Geological Survey OpenFile Report 93-125, 217 p.

Fishman, M.J., and Friedman, L.C., 1989, Methods for determination of inorganic substances in water and fluvial sediments: U.S. Geological Survey Techniques of WaterResources Investigations, book 5, chap. A1, 545 p.

Franson, M.H., ed., 1992, Standard Methods for the Examination of Water and Wastewater. 18th Edition: American Public Health Association, American Water Works Association, and Water Environment Federation, Washington D.C.

Gossett, J.M., and Zinder, S.H., 1996, Microbiological aspects relevant to natural attenuation of chlorinated ethenes: in Proceedings of the Symposium on Natural Attenuation of Chlorinated Organics in Ground Water: EPA/540/R-96/509, Dallas, TX, September 1996.
Hach Company, 1998, DR/2010 Spectrophotometer Procedures Manual: Hach Company, Loveland, CO.

Kampbell, D.H., Wilson, J.T., and Vandergrift, S.A., 1989, Dissolved oxygen and methane in water by a GC headspace equilibrium technique: International Journal of Environ. Analyt. Chem., v. 36, p. 249-457.

McCarty, P.L., and Semprini, L., 1994, Ground-water treatment for chlorinated solvents: in Handbook of Bioremediation, Boca Raton, Lewis Publishers, p. 87-116.

The TEC LTM Team, 2004, DRAFT 2003 annual report Operable Unit 1, Area 1, former base landfill, Naval Undersea Warfare Center Division, Keyport, Washington: Prepared by CH2MHill Constructors, Inc., Seattle, Washington, for Engineering Field Activity, Northwest, Naval Facilities Engineering Command, Poulsbo, WA, 30 p.

URS Consultants, Inc., 1997, Final summary data assessment report for Operable Unit 1 Naval Undersea Warfare Center Division Keyport, Washington: Prepared by URS Consultants, Seattle, Washington, for Engineering Field Activity, Northwest, Naval Facilities Engineering Command, Poulsbo, WA, 3 Volumes.

URS Consultants, Inc., 1998, Final record of decision for Operable Unit 1 Naval Undersea Warfare Center Division Keyport, Washington: Prepared by URS Consultants, Seattle, Washington, for Engineering Field Activity, Northwest, Naval Facilities Engineering Command, Poulsbo, WA, $111 \mathrm{p}$.

URS Greiner, Inc., 1999, Phytoremediation closure report for Operable Unit 1 Naval Undersea Warfare Center Division Keyport, Washington: Prepared by URS Greiner, Inc., Seattle, Washington for En gineering Field Activity, Northwest, Naval Facilities Engineering Command, Poulsbo, WA.

U.S. Geological Survey, 1997 to 2002, National field manual for the collection of water-quality data: U.S. Geological Survey Techniques of Water-Resources Investigations, book 9, chaps. A1-A9, 2 v., variously paged. [Also available online at http://pubs.water.usgs.gov/twri9A. Chapters originally were published from 1997-1999; updates and revisions are ongoing and are summarized at: http://water. usgs.gov/owq/FieldManual/mastererrata.html. 
Manuscript approved for publication, September 9, 2004

Prepared by the Publishing Group, U.S. Geological Survey,

Washington Water Science Center, Tacoma, Washington

USGS Publishing staff

Chester Zenone

Bill Gibbs

Bobbie Jo Richey

For more information concerning the research in this report, contact the Washington Water Science Center Director,

U.S. Geological Survey, 1201 Pacific Avenue - Suite 600

Tacoma, Washington 98402

http://wa.water.usgs.gov 


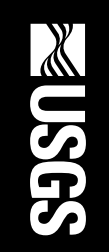

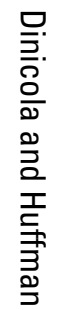

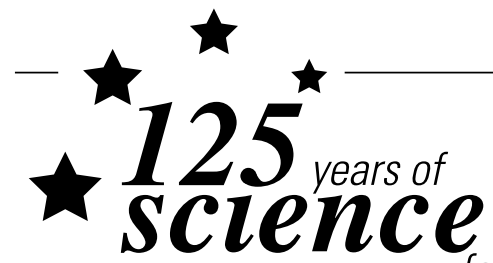

